OPEN ACCESS

Edited by: Gunes Ozhan,

Dokuz Eylül University, Turkey

Reviewed by:

Philippa Francis-West,

King's College London,

United Kingdom

Terry Van Raay,

University of Guelph, Canada

${ }^{*}$ Correspondence:

Susan A. Krum

smirand5@uthsc.edu

Specialty section:

This article was submitted to

Signaling,

a section of the journal

Frontiers in Cell and Developmental

Biology

Received: 13 February 2021

Accepted: 09 April 2021

Published: 04 May 2021

Citation:

Suthon S, Perkins RS, Bryja V Miranda-Carboni GA and Krum SA

(2021) WNT5B in Physiology and Disease.

Front. Cell Dev. Biol. 9:667581 doi: 10.3389/fcell.2021.667581

\section{WNT5B in Physiology and Disease}

\author{
Sarocha Suthon', Rachel S. Perkins' ${ }^{1}$, Vitezslav Bryja ${ }^{2,3}$, Gustavo A. Miranda-Carboni ${ }^{4,5}$ \\ and Susan A. Krum ${ }^{1,5 *}$ \\ ${ }^{1}$ Department of Orthopaedic Surgery and Biomedical Engineering, University of Tennessee Health Science Center, \\ Memphis, TN, United States, ${ }^{2}$ Department of Experimental Biology, Faculty of Science, Masaryk University, Brno, Czechia, \\ ${ }^{3}$ Department of Cytokinetics, Institute of Biophysics, Czech Academy of Sciences, Brno, Czechia, ${ }^{4}$ Division of Hematology \\ and Oncology, Department of Medicine, University of Tennessee Health Science Center, Memphis, TN, United States, \\ ${ }^{5}$ Center for Cancer Research, University of Tennessee Health Science Center, Memphis, TN, United States
}

WNT5B, a member of the WNT family of proteins that is closely related to WNT5A, is required for cell migration, cell proliferation, or cell differentiation in many cell types. WNT5B signals through the non-canonical $\beta$-catenin-independent signaling pathway and often functions as an antagonist of canonical WNT signaling. Although WNT5B has a high amino acid identity with WNT5A and is often assumed to have similar activities, WNT5B often exhibits unique expression patterns and functions. Here, we describe the distinct effects and mechanisms of WNT5B on development, bone, adipose tissue, cardiac tissue, the nervous system, the mammary gland, the lung and hematopoietic cells, compared to WNT5A. We also highlight aberrances in non-canonical WNT5B signaling contributing to diseases such as osteoarthritis, osteoporosis, obesity, type 2 diabetes mellitus, neuropathology, and chronic diseases associated with aging, as well as various cancers.

\section{Keywords: WNT5B, WNT signaling, development, cancer, WNT5A}

\section{INTRODUCTION}

Wingless-related integration site (Wnt) genes are evolutionarily conserved, secreted proteins that are essential for developmental and biological processes. In 1982 the first Int-1 gene was discovered and this proto-oncogene was activated by integration of the mouse mammary tumor virus to induce breast tumors (Nusse and Varmus, 1982), suggesting the importance of Int genes in cancer. The mutation of the wingless $(\mathrm{wg})$ gene in Drosophila created the wingless phenotype (Sharma and Chopra, 1976) by interrupted segment polarity in fly larva (Rijsewijk et al., 1987), indicating its role in development. Over 30 years ago, the $w g$ gene was shown to be a homolog with the mouse Int-1 gene, leading to a combination of these two names to WNT (Rijsewijk et al., 1987).

The WNT family now contains 19 WNT genes, falling into 12 WNT subfamilies in mammalian genomes. All WNT genes encode proteins around $40 \mathrm{kDa}$ in size and contain highly conserved cysteines (Miller, 2002; Clevers and Nusse, 2012). Mammalian WNT proteins are palmitoylated at conserved serine residues by a special palmitoyl transferase, Porcupine (PORCN), in the endoplasmic reticulum (Takada et al., 2006; Galli et al., 2007; Rios-Esteves et al., 2014). Zebrafish WNT3 is lipidated at both cysteine and serine residues (Dhasmana et al., 2021). The activity of PORCN is essential for the secretion of WNT ligands. Then, the seven-transmembrane protein Wntless/Evi (Wls) in the endoplasmic reticulum escorts mature hydrophobic WNT proteins to be secreted at the plasma membrane or released in exosomes, leading to both autocrine and paracrine effects (Banziger et al., 2006; Routledge and Scholpp, 2019). 
The WNT signaling pathway is divided into two main branches: the non-canonical ( $\beta$-catenin-independent) signaling pathway and the canonical ( $\beta$-catenin-dependent) signaling pathway (Figure 1). WNT ligands bind to various receptors and co-receptors. There are 10 members of the Frizzled (FZD) protein family, which serve as receptors for both the canonical and non-canonical signaling pathways. The pairing between specific FZDs and another receptor, such as low-density lipoprotein receptor-related protein 5 or 6 (LRP5/6), receptor Tyr kinaselike orphan receptor 1 or $2(\mathrm{ROR} 1 / 2)$ and receptor Tyr kinase (RYK), directs the downstream signaling pathway (Azbazdar et al., 2021). Canonical WNT signaling is initiated by binding of WNT ligands (e.g., WNT3A and WNT10B) to a heterodimeric receptor complex formed by a Frizzled (FZD) and LRP5/6. The signaling output of the canonical WNT pathway is determined by the level of cytosolic $\beta$-catenin, which is under the strict control of the destruction complex. The destruction complex is composed of APC (Adenomatous Polyposis Coli), AXIN1, and two constitutively active kinases [glycogen synthase kinase (i.e., GSK $3 \beta$ ) and casein kinase (i.e., $\mathrm{CK} 1 \alpha$ )], which associate with $\beta$-catenin and promote its polyubiquitination by phosphorylating the degron motif of $\beta$-catenin (Stamos and Weis, 2013). Subsequently, phosphorylated $\beta$-catenin can be recognized by the F-box/WD-repeat protein $\beta$-TrCP within the SCF ubiquitin ligase complex, which facilitates the targeting of cytosolic $\beta$-catenin, leading to its proteasome-dependent degradation (Hart et al., 1999; Kitagawa et al., 1999). Binding of WNT ligands with FZD/LRP receptors induces stoichiometric sequestration of the destruction complex components AXIN1/CK1 $\alpha /$ GSK3 onto the receptor complex and phosphorylation of LRP5/6, which are enhanced by Disheveled family members (DVL1-3). Receptor engagement leads to the accumulation of cytoplasmic $\beta$-catenin, which translocates into the nucleus, where it binds to members of the $\mathrm{T}$ cell factor/lymphoid enhancer factor (TCF/LEF) transcription factor family to drive transcription of WNT/ $\beta$-catenin target genes such as AXIN2 and MYC (amongst others) (Lecarpentier et al., 2019).

Some WNT ligands (e.g., WNT5A and WNT5B) can activate non-canonical WNT pathways, which are independent of $\beta$ catenin stabilization (Xiao et al., 2017). Non-canonical WNT signaling pathways are subdivided into the WNT-planar cell polarity (WNT-PCP) signaling pathway and the WNT-calcium (WNT-Ca ${ }^{2+}$ ) signaling pathway. Although these two pathways show overlapping receptors such as ROR and RYK, they utilize different downstream effectors (Chen et al., 2021). In the WNTPCP signaling pathway, Disheveled (DVL) forms a complex with DVL-associated activator of morphogenesis 1 (DAMM1) to induce the small GTPase Ras homology family member (Rho) activation (Habas et al., 2001). Then Rho activates downstream kinases such as Rho-associated protein kinase (ROCK) (Winter et al., 2001) or JUN-N-terminal kinase (JNK) (Strutt et al., 1997). Alternatively, DVL activates RAC to trigger JNK activity, which controls gene expression via JNK-dependent transcription factors (Fanto et al., 2000). The activation of WNT-PCP signaling results in cell polarity, cell migration and convergent extension [Convergent extension (CE) is a critical process by which the tissue of an embryo is restructured to converge (narrow) along one axis and extend (elongate) along a perpendicular axis by cellular movement] (Niehrs, 2012). The WNT-Ca ${ }^{2+}$ signaling pathway activates heterotrimeric $\mathrm{G}$ proteins to trigger phospholipase C (PLC) activity, which stimulates diacylglycerol (DAG) and inositol-1,4,5-triphosphate, type 3 (IP3) production leading to intracellular calcium flux (Slusarski et al., 1997), as well as calcineurin, calmodulin-dependent kinase II (CaMKII) and protein kinase C (PKC) activation (Kuhl et al., 2000; Wang et al., 2010). In addition, the transcriptional regulator nuclear factor associated with $\underline{T}$ cells (NFAT) is stimulated via the YES/CDC42/CK1 $\alpha$ pathway and is translocated to the nucleus to control transcription of genes involved in morphogenesis, mesenchymal to epithelial transition and metastasis (Dejmek et al., 2006; Burn et al., 2011).

Herein, the review will focus on non-canonical WNT5B signaling and its role in both normal physiology and disease, especially in comparison to WNT5A.

\section{WNT5B ACTIVITY AND SIGNALING}

The WNT5 subfamily of WNT proteins consists of WNT5A and WNT5B. The Wnt5 gene is present in Cnidarians (diploblastic animals including freshwater polyps and hydroids, sea anemones and corals, and jellyfish) (Guder et al., 2006). Duplication can be observed in Xenopus, but not in all chordates, such as chickens. WNT5B is the genetic paralog of WNT5A (Bergstein et al., 1997). They have 87 and $80.5 \%$ amino acid identity in mice and humans, respectively (Gavin et al., 1990; Saitoh and Katoh, 2001). Both WNT5A and WNT5B show similar expression patterns and functions in some cell types, such as cardiomyocytes (Mazzotta et al., 2016; Albanese et al., 2017) and lung fibroblasts (van Dijk et al., 2016; Wu et al., 2019). However, WNT5A and WNT5B are expressed in non-overlapping patterns during mouse development (Gavin et al., 1990; Lickert et al., 2001; Church et al., 2002), suggesting that WNT5A and WNT5B activity are distinctly different during embryogenesis. Moreover, distinct effects of WNT5A and WNT5B are found in chondrocytes (Church et al., 2002; Yang et al., 2003), bone (Maeda et al., 2012; Brommage et al., 2014), adipocytes (Kanazawa et al., 2005; Maeda et al., 2012), mammary epithelial cells (Kessenbrock et al., 2017), and myeloid cells (de Rezende et al., 2020; see Table 1 and specific tissues below).

$W n t 5 b$ was first identified in 1990 and was found to be expressed during embryogenic development (Gavin et al., 1990). Mouse $W n t 5 b$ is located on chromosome 6 (Church et al., 2009) and encodes a $3.2 \mathrm{~kb}$ single RNA species (Gavin et al., 1990) and in turn, 49 and $46.5 \mathrm{kDa}$ proteins can be visualized by immunoblotting after post-translational modification (Smolich et al., 1993). Although mouse and human WNT5B show $87.74 \%$ gene similarity and $94 \%$ amino acid identity $^{1}$, the rodent $W n t 5 b$ promoter and human WNT5B promoter are significantly divergent (Katoh and Katoh, 2005). Human WNT5B, located at chromosome 12p13.33 (Saitoh and Katoh, 2001), has 4 exons and alternative promotors that

\footnotetext{
${ }^{1}$ www.genecards.org
} 


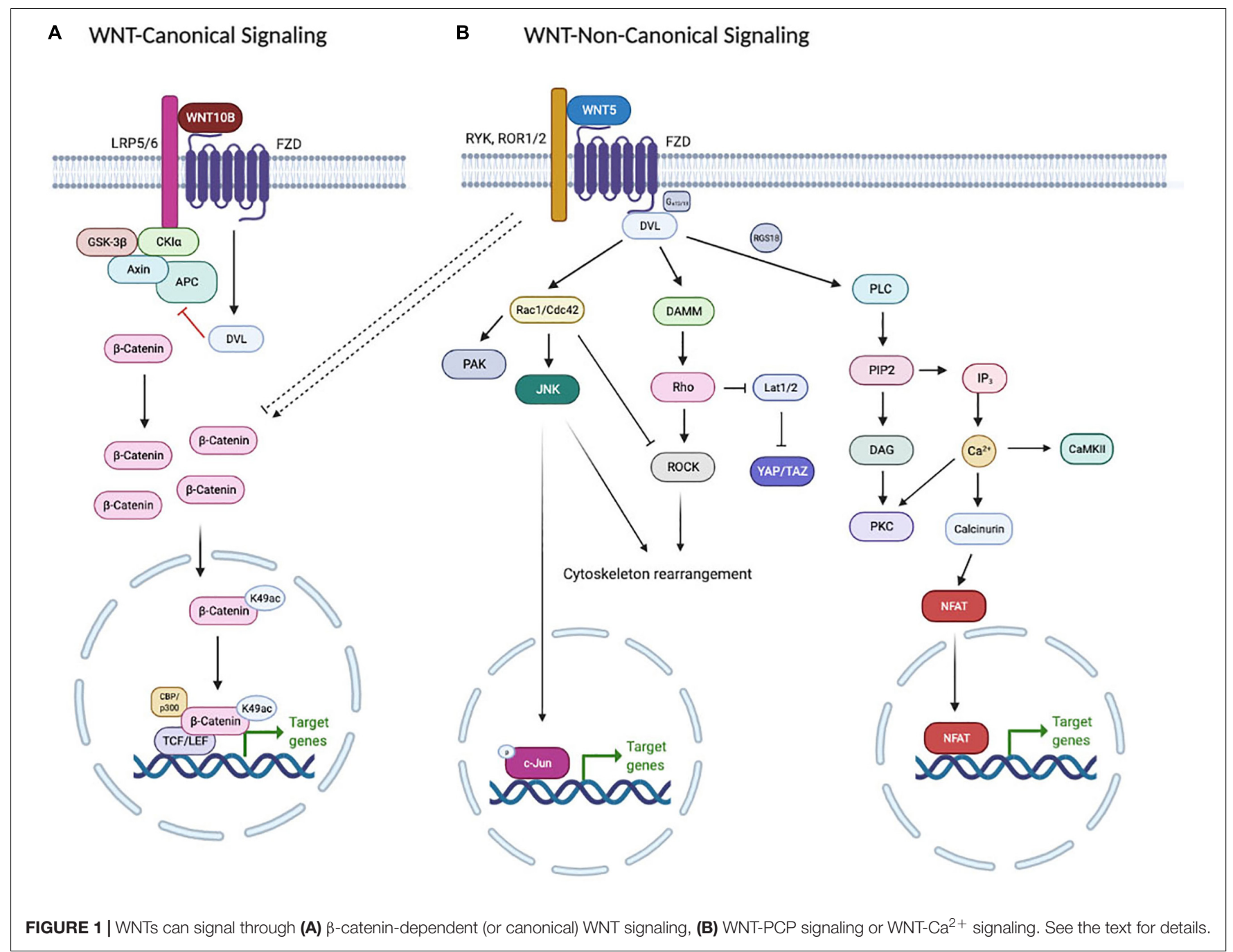

encode WNT5B into two isoforms differing at the first exon: isoform 1 (NM_032642.2) consists of exon 1A and isoform 2 (NM_030775.2) consists of exon 1B. Exons $1 \mathrm{~A}$ and $1 \mathrm{~B}$ correspond to the $5^{\prime}$-UTR, while exon 2 contains the starting methionine (Katoh and Katoh, 2005). The consequence of the differing exon usage is unknown.

WNT5B functions through the non-canonical WNT signaling pathway (Lin et al., 2010; Bradley and Drissi, 2011; Park et al., 2015; van Dijk et al., 2016; Mattes et al., 2018). While it is called $\beta$-catenin-independent signaling, WNT5B is often an antagonist to $\beta$-catenin signaling (Santiago et al., 2012; Mattes et al., 2018; Wu et al., 2019; Figure 1). The receptors and coreceptors [FZD protein(s)] to which WNT5B binds is still controversial. A structure-based prediction shows that the cystine-rich domain of FZD6 binds with WNT5B into a palm-shaped opening structure (Dahiya et al., 2019) and then activates a small $G_{0}$ protein (Katanaev and Buestorf, 2009). In contrast, fluorescence recovery after photobleaching (FRAP) revealed that WNT5B did not affect FZD6 mobility, suggesting a lack of WNT5B-FZD6 interactions, at least in the HEK293T model system (Kilander et al., 2014). In silico analysis predicts that FZD8 has the highest affinity (Agostino et al., 2017; Dahiya et al., 2019), while in vitro and in vivo studies show that WNT5B can bind to FZD1 (Park et al., 2015), FZD2 (van Dijk et al., 2016), FZD4 (Mazzotta et al., 2016; Sarin et al., 2018), FZD5 (Sarin et al., 2018), FZD6 (Katanaev and Buestorf, 2009; Mazzotta et al., 2016), and FZD7 (Yin et al., 2020).

\section{ROLE OF WNT5B IN DEVELOPMENT}

WNT signaling is crucial for embryonic development in all animal species and the topic has been well-reviewed by others (van Amerongen and Nusse, 2009; Steinhart and Angers, 2018). The role of WNT5B signaling in embryonic development is less clear. In general, WNT signaling in embryonic development is context-dependent in both invertebrates and vertebrates. In embryos, WNT signaling has definitive roles for ventraldorsal and anterior-posterior organization during various stages of early development. The organization of cells requires different WNT inputs to mediate planar cell polarity (PCP) during developmental processes such as gastrulation and 
TABLE 1 | Distinct effects of WNT5A and WNT5B.

\begin{tabular}{|c|c|c|c|c|c|}
\hline Organ/Tissue & Cell type & WNT5A & References & WNT5B & References \\
\hline Embryo & & Controls convergent extension (z) & Ye et al., 2013 & Controls convergent extension (z) & Ye et al., 2013 \\
\hline Palate & & Knockouts had a short palate (z) & He et al., 2008 & Knockouts had a short palate (z) & $\begin{array}{l}\text { Rochard et al., } \\
2016\end{array}$ \\
\hline \multirow[t]{5}{*}{ Bone } & & $\begin{array}{l}\text { Wnt5a-/- showed skeletal defects } \\
\text { in the mouse fetus }(\mathrm{m}) \\
\text { Wnt5a } \\
\text { mass }(\mathrm{m})\end{array}$ & $\begin{array}{l}\text { Yamaguchi et al., } \\
1999 \\
\text { Maeda et al., } 2012\end{array}$ & $\begin{array}{l}\text { High-throughput Wnt5b-/- slightly } \\
\text { increased bone mass }(\mathrm{m})\end{array}$ & $\begin{array}{l}\text { Brommage et al., } \\
2014\end{array}$ \\
\hline & Chondrocyte & $\begin{array}{l}\text { Expressed at joint and } \\
\text { perichondrium (c) } \\
\text { Activated transition from } \\
\text { proliferative chondrocyte zone to } \\
\text { pre-hypertrophy zone by repressing } \\
\text { Ccnd1, Sox9, and Col2a1, while } \\
\text { increasing p130 (m) }\end{array}$ & $\begin{array}{l}\text { Church et al., } 2002 \\
\text { Yang et al., } 2003\end{array}$ & $\begin{array}{l}\text { Expressed at pre-hypertrophic zone (c) } \\
\text { Promoted proliferative chondrocyte } \\
\text { zone but suppressed the transition to } \\
\text { pre-hypertrophy zone by elevating } \\
\text { Ccnd1, Sox9, and Col2a1, while } \\
\text { suppressed p130 (m) }\end{array}$ & $\begin{array}{l}\text { Church et al., } 2002 \\
\text { Yang et al., } 2003\end{array}$ \\
\hline & Osteoblast & $\begin{array}{l}\text { Promoted osteoblastogenesis by } \\
\text { upregulating } L \text { rp } 5 / 6 \text { expression and } \\
\text { activating } \beta \text {-catenin-dependent } \\
\text { signaling pathway (m) }\end{array}$ & $\begin{array}{l}\text { Okamoto et al., } \\
2014\end{array}$ & No report of the mechanism of action & \\
\hline & Osteoclast & $\begin{array}{l}\text { Increased osteoclastogenesis by } \\
\text { upregulating RANK through } \\
\text { ROR2/JNK signaling pathway (m) }\end{array}$ & Maeda et al., 2012 & $\begin{array}{l}\text { Activated osteoclast differentiation via } \\
\text { RYK receptor (murine RAW264.7 } \\
\text { monocytic cells) }\end{array}$ & $\begin{array}{l}\text { Santiago et al., } \\
2012\end{array}$ \\
\hline & $\begin{array}{l}\text { Synovial } \\
\text { mesenchymal } \\
\text { stem cell }\end{array}$ & $\begin{array}{l}\text { Aggravated joint degeneration by } \\
\text { inducing senescence and } \\
\text { inflammatory cytokines (h) }\end{array}$ & Huang et al., 2020 & $\begin{array}{l}\text { Promoted joint degeneration by } \\
\text { inhibiting chondrocyte differentiation } \\
\text { and ECM secretion (h) }\end{array}$ & Huang et al., 2020 \\
\hline Adipose tissue & Adipocyte & Suppressed adipogenesis (r) & Tang et al., 2018 & $\begin{array}{l}\text { Promoted adipogenesis and increased } \\
\text { the level of } P P A R \gamma, C / E B P-\alpha, A D I P O Q \\
\text { and } L E P \text { (mouse } 3 T 3-L 1 \text { cell line) } \\
\text { Inhibited nuclear translocation of } \\
\beta \text {-catenin (mouse 3T3-L1 cell line) }\end{array}$ & $\begin{array}{l}\text { Kanazawa et al., } \\
2004 \\
\text { Kanazawa et al., } \\
2005\end{array}$ \\
\hline Pancreas & $\beta$-cell & $\begin{array}{l}\text { Less expressed and colocalized } \\
\text { with insulin- and } \\
\text { glucagon-immunoreactive cells (m) } \\
\text { No effect on NKX6.1 production in } \\
\text { human iPSC (h) }\end{array}$ & $\begin{array}{l}\text { Heller et al., } 2002 \\
\text { Vethe et al., } 2019\end{array}$ & $\begin{array}{l}\text { Strongly expressed and localized with } \\
\text { insulin- and glucagon-immunoreactive } \\
\text { cells (m) } \\
\text { Increased the level of NKX6.1 in human } \\
\text { iPSC (h) }\end{array}$ & $\begin{array}{l}\text { Heller et al., } 2002 \\
\text { Vethe et al., } 2019\end{array}$ \\
\hline Cardiac tissue & Cardiomyocyte & $\begin{array}{l}\text { No effect on pacemaker } \\
\text { differentiation }(z / h)\end{array}$ & Ren et al., 2019 & $\begin{array}{l}\text { Induced pacemaker differentiation } \\
\text { through activating } \beta \text {-catenin-dependent } \\
\text { signaling pathway }(\mathrm{z} / \mathrm{h})\end{array}$ & Ren et al., 2019 \\
\hline \multirow[t]{4}{*}{$\begin{array}{l}\text { Nervous } \\
\text { system }\end{array}$} & $\begin{array}{l}\text { Differentiated } \\
\text { neural stem cell }\end{array}$ & $\begin{array}{l}\text { Slightly increased in differentiated } \\
\text { cells }(\mathrm{m})\end{array}$ & Choi et al., 2011 & Highly elevated in differentiated cells (m) & Choi et al., 2011 \\
\hline & $\begin{array}{l}\text { Dorsal ganglia } \\
\text { root and spinal } \\
\text { cord dorsal } \\
\text { horn }\end{array}$ & $\begin{array}{l}\text { Decreased after morphine } \\
\text { treatment and morphine } \\
\text { withdrawal }(\mathrm{m})\end{array}$ & Wu et al., 2020 & $\begin{array}{l}\text { Strongly increased after morphine } \\
\text { treatment and morphine withdrawal (m) }\end{array}$ & Wu et al., 2020 \\
\hline & $\begin{array}{l}\text { Hippocampal } \\
\text { dentate gyrus }\end{array}$ & $\begin{array}{l}\text { Downregulated in ictal zone and } \\
\text { peri-ictal zone after seizure }(\mathrm{m})\end{array}$ & $\begin{array}{l}\text { Gupta and Schnell, } \\
2019\end{array}$ & $\begin{array}{l}\text { Elevated in ictal zone but reduced in } \\
\text { peri-ictal zone after seizure }(\mathrm{m})\end{array}$ & $\begin{array}{l}\text { Gupta and Schnell, } \\
2019\end{array}$ \\
\hline & $\begin{array}{l}\text { Mechano- } \\
\text { sensory } \\
\text { Cell }\end{array}$ & $\begin{array}{l}\text { No effect on cilia-mediated } \\
\text { mechanosensory cells (z) }\end{array}$ & $\begin{array}{l}\text { Louwette et al., } \\
2012\end{array}$ & $\begin{array}{l}\text { Induced ciliogenesis in inner ear and } \\
\text { migration of neuromast (z) }\end{array}$ & $\begin{array}{l}\text { Louwette et al., } \\
2012\end{array}$ \\
\hline $\begin{array}{l}\text { Mammary } \\
\text { gland }\end{array}$ & $\begin{array}{l}\text { Mammary } \\
\text { epithelial cell }\end{array}$ & $\begin{array}{l}\text { Endogenously expressed and } \\
\text { unable to transform C57MG cell } \\
\text { morphology } \\
\text { Increased mammosphere formation } \\
\text { through RYK receptor (m) } \\
\text { Inhibited mammary gland } \\
\text { branching via ROR2 receptor (m) }\end{array}$ & $\begin{array}{l}\text { Wong et al., } 1994 \\
\text { Kessenbrock et al., } \\
2017\end{array}$ & $\begin{array}{l}\text { Exogenously expressed and induced } \\
\text { C57MG morphological transformation } \\
\text { Suppressed mammosphere formation } \\
\text { through ROR2 and RYK-independent } \\
\text { receptors (m) } \\
\text { No effect on mammary gland } \\
\text { branching (m) }\end{array}$ & $\begin{array}{l}\text { Wong et al., } 1994 \\
\text { Kessenbrock et al., } \\
2017\end{array}$ \\
\hline Lung & $\begin{array}{l}\text { Alveolar } \\
\text { epithelial } \\
\text { progenitors } \\
\text { (AEPs) }\end{array}$ & $\begin{array}{l}\text { Represses the growth of lung } \\
\text { organoid co-cultures of fibroblasts } \\
\text { and epithelial progenitors (m) } \\
\text { Highly expressed in COPD (h) }\end{array}$ & $\begin{array}{l}\text { Wu et al., } 2019 \\
\text { van Dijk et al., } 2016\end{array}$ & $\begin{array}{l}\text { Represses the growth of lung organoid } \\
\text { co-cultures of fibroblasts and epithelial } \\
\text { progenitors (m) } \\
\text { Represses the growth and } \\
\text { differentiation of AEPs (m) } \\
\text { Highly expressed in COPD (h) }\end{array}$ & $\begin{array}{l}\text { Wu et al., } 2019 \\
\text { van Dijk et al., } 2016\end{array}$ \\
\hline
\end{tabular}


TABLE 1 | Continued

\begin{tabular}{|c|c|c|c|c|c|}
\hline Organ/Tissue & Cell type & WNT5A & References & WNT5B & References \\
\hline \multirow[t]{4}{*}{ Immune system } & Myeloid cells & $\begin{array}{l}\text { No effect on IL-3 and } \\
\text { GM-CSF-induced myeloid } \\
\text { differentiation (m) } \\
\text { Knockdown Wnt5a did not affect } \\
\text { thrombocyte production (z) }\end{array}$ & $\begin{array}{l}\text { de Rezende et al., } \\
2020 \\
\text { Louwette et al., } \\
2012\end{array}$ & $\begin{array}{l}\text { Exhibited divergent effects on IL-3 } \\
\text { and GM-CSF-induced myeloid } \\
\text { differentiation (m) } \\
\text { Knockdown Wnt5b showed severe } \\
\text { thrombocytopenia (z) }\end{array}$ & $\begin{array}{l}\text { de Rezende et al., } \\
2020 \\
\text { Louwette et al., } \\
2012\end{array}$ \\
\hline & T cells & $\begin{array}{l}\text { Not expressed in thymocytes, } \\
\text { peripheral T cells and epithelial } \\
\text { cells (m) }\end{array}$ & $\begin{array}{l}\text { Balciunaite et al., } \\
2002\end{array}$ & $\begin{array}{l}\text { Expressed in thymocytes, peripheral } \\
\text { T cells and epithelial cells }(\mathrm{m}) \\
\text { Highly expressed in CD4 }{ }^{+} \mathrm{CD}^{+} \\
\text {double positive thymocytes and } \\
\text { decreases by } 75-95 \% \text { during later } \\
\text { stages of T cell development (m) }\end{array}$ & $\begin{array}{l}\text { Balciunaite et al., } \\
2002\end{array}$ \\
\hline & Whole blood & $\begin{array}{l}\text { No change in expression in septic } \\
\text { shock }(\mathrm{m} / \mathrm{h})\end{array}$ & $\begin{array}{l}\text { Gatica-Andrades } \\
\text { et al., } 2017\end{array}$ & $\begin{array}{l}\text { Increased expression in septic shock } \\
\text { and correlated with IL-6, IL-10, and } \\
\text { TNF (m/h) }\end{array}$ & $\begin{array}{l}\text { Gatica-Andrades } \\
\text { et al., } 2017\end{array}$ \\
\hline & $\begin{array}{l}\text { Lymphatic } \\
\text { system }\end{array}$ & $\begin{array}{l}\text { Increased migration of lymphatic } \\
\text { endothelial cells, leading to } \\
\text { elongated tube formation. (m) }\end{array}$ & Lutze et al., 2019 & $\begin{array}{l}\text { Necessary and sufficient for lymphatic } \\
\text { endothelial specification (z/h) } \\
\text { Enhances the lymph vessel } \\
\text { formation, permeability and migration } \\
\text { of lymphatic endothelial cell (h) }\end{array}$ & $\begin{array}{l}\text { Nicenboim et al., } \\
2015 \\
\text { Wang et al., } 2017\end{array}$ \\
\hline \multirow[t]{10}{*}{ Cancer } & Breast cancer & $\begin{array}{l}\text { Controversial: Correlated with } \\
\text { better prognosis and induced } \\
\text { tumorigenicity (h) }\end{array}$ & Zeng et al., 2016 & $\begin{array}{l}\text { Correlated with a worse prognosis in } \\
\text { BLBC (h) }\end{array}$ & $\begin{array}{l}\text { Yang et al., 2014; } \\
\text { Jiang et al., } 2019\end{array}$ \\
\hline & $\begin{array}{l}\text { Colorectal } \\
\text { cancer }\end{array}$ & $\begin{array}{l}\text { Promotes migration and invasion } \\
\text { (h) } \\
\text { Inhibits cell proliferation and EMT } \\
\text { (h) }\end{array}$ & $\begin{array}{l}\text { Bakker et al., } 2013 \\
\text { Cheng et al., } 2014\end{array}$ & $\begin{array}{l}\text { Promoted cell proliferation, migration } \\
\text { and invasion through the JNK } \\
\text { signaling pathway (h) }\end{array}$ & Zhang et al., 2016 \\
\hline & $\begin{array}{l}\text { Pancreatic } \\
\text { cancer }\end{array}$ & $\begin{array}{l}\text { Leads to pancreatic cancer } \\
\text { progression and } \\
\text { chemo-resistance }(\mathrm{h})\end{array}$ & $\begin{array}{l}\text { Wei et al., 2014; Bo } \\
\text { et al., 2016; Ram } \\
\text { Makena et al., } 2019\end{array}$ & Not studied & \\
\hline & Lung cancer & $\begin{array}{l}\text { Overexpressed in } \\
\text { NSCLC compared to normal } \\
\text { tissue (h) } \\
\text { Overexpression is correlated with } \\
\text { poor overall survival (h) }\end{array}$ & $\begin{array}{l}\text { Huang et al., 2005; } \\
\text { Zhang et al., } 2020\end{array}$ & $\begin{array}{l}\text { Overexpressed in NSCLC compared } \\
\text { to normal tissue (h) } \\
\text { Overexpression is correlated with } \\
\text { poor overall survival (h) }\end{array}$ & $\begin{array}{l}\text { Huang et al., 2005; } \\
\text { Zhang et al., } 2020\end{array}$ \\
\hline & $\begin{array}{l}\text { Oral squamous } \\
\text { cell carcinoma }\end{array}$ & $\begin{array}{l}\text { TGF- } \beta 1 \text { stimulated Slug which } \\
\text { decreased WNT5A expression (h) }\end{array}$ & Hino et al., 2016 & $\begin{array}{l}\text { TGF- } \beta 1 \text { stimulated Slug which } \\
\text { increased WNT5B expression (h) }\end{array}$ & Hino et al., 2016 \\
\hline & Osteosarcoma & $\begin{array}{l}\text { Correlated with advanced } \\
\text { surgical stage and tumor } \\
\text { metastasis (h) } \\
\text { Increased migration and invasion } \\
\text { of osteosarcoma cell lines (h) }\end{array}$ & $\begin{array}{l}\text { Lu et al., } 2012 . \\
\text { Enomoto et al., } \\
\text { 2009; Wang et al., } \\
2018\end{array}$ & $\begin{array}{l}\text { Similarly expressed compared to the } \\
\text { expression of } R O R 2(\mathrm{~h}) \\
\text { No study on the function in } \\
\text { osteosarcoma }\end{array}$ & Morioka et al., 2009 \\
\hline & Ovarian cancer & $\begin{array}{l}\text { Suppresses growth of epithelial } \\
\text { ovarian cancer (h) }\end{array}$ & Bitler et al., 2011 & Increases stemness (h) & $\begin{array}{l}\text { Raghavan et al., } \\
2019\end{array}$ \\
\hline & Brain cancer & $\begin{array}{l}\text { Correlated with overall worse } \\
\text { survival (h) }\end{array}$ & Xu et al., 2020 & $\begin{array}{l}\text { Correlated with better overall survival } \\
\text { (h) }\end{array}$ & Xu et al., 2020 \\
\hline & $\begin{array}{l}\text { Hepato-cellular } \\
\text { carcinoma }\end{array}$ & $\begin{array}{l}\text { No significant difference in } \\
\text { WNT5A expression in tumor and } \\
\text { adjacent-normal tissue (h) }\end{array}$ & Dong et al., 2019 & $\begin{array}{l}\text { High expression in tumor compared } \\
\text { to adjacent-normal tissue (h) }\end{array}$ & Dong et al., 2019 \\
\hline & Leukemia & $\begin{array}{l}\text { Highly expressed in CLL and } \\
\text { correlates with CLL } \\
\text { aggressiveness (h) } \\
\text { Expression is lost in AML (h) }\end{array}$ & $\begin{array}{l}\text { Janovska et al., } \\
2016 \\
\text { Martin et al., } 2010\end{array}$ & Highly expressed in CLL and AML (h) & $\begin{array}{l}\text { Janovska et al., } \\
2016 \\
\text { Zheng et al., } 2017\end{array}$ \\
\hline
\end{tabular}

z, zebrafish; c, chicken; $m$, mouse; r, rat; and h, human.

neural tube closure. The polarization of node cells along the anterior-posterior axis of a mouse embryo was mostly unknown until the discovery of the asymmetric expression of Wnt5a and $W n t 5 b$ in the posterior side, which coincided with an anterior expression of WNT inhibitor SFRP (Minegishi et al., 2017). The opposing distribution of $W n t 5 a / W n t 5 b$ gradients with that of SFRP guides intercellular signaling via PCP to polarize the cells along the anterior-posterior axis and to make a break of the left-right symmetry of the cells. The data suggest that WNT5A/5B have a redundant role in governing the break of left-right symmetry in cells, but it is unknown exactly which receptor/pathway this action is mediated through. 
Vertebrate gastrulation is critical to establishing the germ layer and to coordinate the body axes, which are guided by cell movements. During gastrulation in zebrafish development, silencing of focal adhesion kinase (FAK1A) utilizing morpholinos led to the loss of convergent extension, impaired epiboly (cellular movement of squamous epithelium) and hypoblast cell migration. FAK1A combined with WNT5B rescued convergent extensions mediated by the FAK1A phenotype (Hung et al., 2020). Conversely, an injection of subthreshold levels of Wnt5b antisense morpholino oligonucleotides led to enhanced loss of convergent extension in the null FAK1A zebrafish. The results suggest that gradient increases of $W n t 5 b$ expression change or hamper or complement the loss of FAK1A activity on CE. Furthermore, CE was mediated by RAC1 and CDC42 actin dynamics. WNT5A also regulates convergent extensions in the zebrafish embryo (Ye et al., 2013).

Palate morphogenesis in the zebrafish at E4.5 is also formed by CE (Rochard et al., 2016). Wnt5b knockout zebrafish had a short palate. The ablation of $W n t 5 b$ affected the columnar organization but not the single layer stacking during CE. These results demonstrate that WNT5B controls the anterior-posterior axis in palate formation. WNT5A also regulates the anterior-posterior axis of the palate, similar to WNT5B (He et al., 2008). Interestingly, a translocation in the WNT5A locus has been implicated in human cleft palates (Blanton et al., 2004).

Cilia and basal bodies on the cell help control convergent extension. Basal body proteins [encoded by $b b s 1, b b s 4$, and bbs6 (mkks)] were found to interact with WNT11 and WNT5B and signal through the WNT-PCP pathway (Gerdes et al., 2007). Knockout of BBS4 produced the strongest phenotype, as determined by defective tail extension. The authors suggest that WNT11 and WNT5B may have partially redundant roles, as mutants fail to extend axial tissues in zebrafish. Moreover, BBS4 was also shown to affect canonical WNT signaling in a mammalian cell system (using HEK293T cells) to measure ciliary function. Upon BBS4 suppression, $\beta$-CATENIN accumulated and increased nuclear Disheveled 3 (DVL3) localization, with increases in corresponding WNT reporter activity. Mechanistically, the authors link the stability of $\beta$-CATENIN protein degradation, in the absence of BBS4 expression, to BBS4's ability to physically interact with the proteasomal subunit RPN10. These results demonstrate a link between $\mathrm{WNT} / \beta$-catenin signaling and non-canonical signaling (WNT-PCP) in convergent extension.

\section{ROLE OF WNT5B IN BONE}

WNT5B is involved in many aspects of bone physiology, including bone formation, bone maintenance and bone degradation. Wnt5b is expressed in mouse limb development; meanwhile, Wnt5a was not detected (Witte et al., 2009). In total long bone extracts, $W n t 5 b$ has the highest expression in young mouse bone ( 6 weeks old), decreases by adulthood ( 6 months old) and remains constant in aged mice (18 months old). $W n t 5 a$ shows the same pattern of expression, but its expression level is fourfold lower compared to $W n t 5 b$ at each timepoint (Rauner et al., 2008).

WNT5B is expressed in mesenchymal stem cells (MSCs) (Fazzi et al., 2011; Charoenpanich et al., 2014) and the lineage cells, including chondrocytes (Church et al., 2002; Bradley and Drissi, 2011; Duesterdieck-Zellmer et al., 2015) and osteoblasts (Rauner et al., 2008). WNT5B is also expressed in osteoclasts (Santiago et al., 2012). WNT5A also has high expression in MSCs, as does WNT5B (Fazzi et al., 2011), but the level of WNT5A is higher than WNT5B in osteoblasts (Maeda et al., 2012; Kemp et al., 2014), adipose tissues (Akoumianakis et al., 2019), as well as osteoclast precursor bone marrow-derived macrophages (Maeda et al., 2012). High-throughput knockout of $W n t 5 b$ revealed an increase in bone mineral density (BMD) (Brommage et al., 2014), indicating that WNT5B affects bone negatively, but this has not been investigated beyond analyzing BMD. In comparison, knockout of $W n t 5 a$ results in skeletal defects in the mouse fetus and perinatal lethality (Yamaguchi et al., 1999). $W n t 5 a^{ \pm}$mice exhibit low bone mass with decreases in both osteoblastogenesis and osteoclastogenesis (Maeda et al., 2012), in contrast to the high bone mass in $W n t 5 b$ knockout mice. The skeletal phenotype of the WNT5A knockout mouse is also due to its proliferative and PCP effects in mesenchyme (Andre et al., 2015). The role of WNT5B in specific bone cells (chondrocytes, osteoblasts and osteoclasts) (Figure 2) and bone diseases (osteoarthritis and osteoporosis) is discussed below.

\section{Chondrocytes}

Endochondral ossification is the major process for long bone formation in which mesenchymal cells must first condense and differentiate into chondrocytes to establish a cartilaginous structure before gradually being replaced by bone cells. During this process, chondrocyte regions can be divided into two zones, Zone I (articular and resting chondrocytes) and Zone II (proliferative chondrocytes), depending on cell morphologies, developmental functions and fates. Zone I corresponds to the epiphysis and contains two cell types: articular chondrocytes which will become permanent articular cartilage to maintain normal joint function throughout life and resting chondrocytes, which contain stem cell-like activity and embed into the growth plate (Abad et al., 2002). Meanwhile, Zone II maintains highly proliferative chondrocytes in the growth plate, which will undergo hypertrophy. The proliferative activity of Zone II is dependent on Zone I and requires tight regulation from systemic and local factors (Hunziker, 1994; Karp et al., 2000).

WNT5B is highly expressed in cartilage canal chondrocytes during neonatal development (Duesterdieck-Zellmer et al., 2015). In long bones, WNT5B is restricted to the prehypertrophic zone (Zone II) (Church et al., 2002), and acts as a local factor to activate proliferation of chondrocytes in Zone I by downregulation of $p 130$ (an Rb family transcription factor) and upregulation of Ccnd1, Sox9, and Col2a1, leading to the promotion of Zone II formation (Yang et al., 2003; Figure 2). Overexpression of $W n t 5 b$ delays terminal chondrocyte differentiation and hypertrophy by suppressing Col10a1 expression, and results in an open skull, shortened long bones and reduced ossification in the embryo (Yang et al., 2003). 


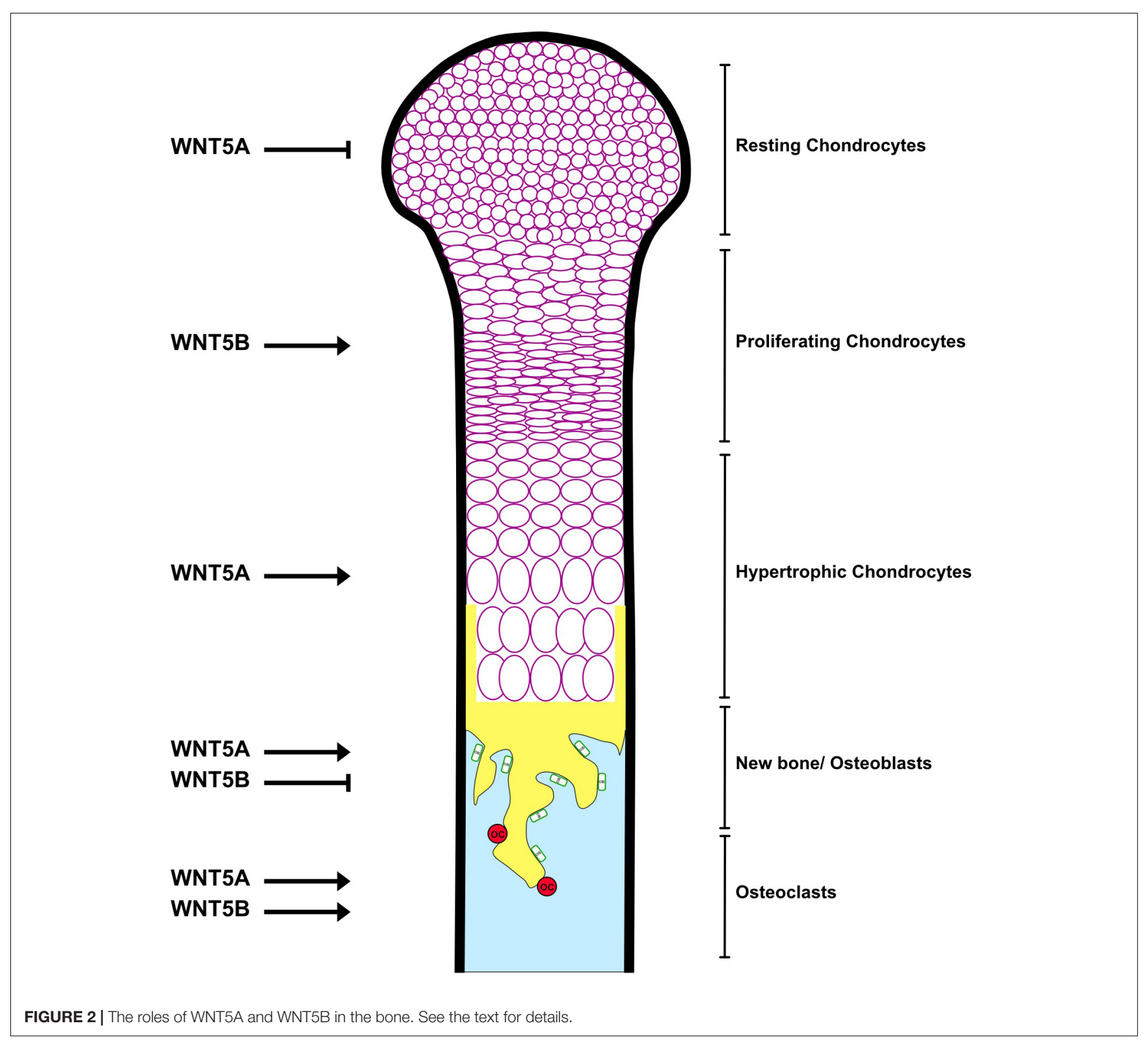

Interestingly, misexpression of Wnt5b causes shortened limbs (Church et al., 2002), suggesting that precise conditions of WNT5B are important to regulate endochondral ossification.

WNT5B also controls other processes involved in cartilage development. WNT5B is required for craniofacial cartilage development in zebrafish. WNT5B regulates chondrocyte stacking in a Wnt/PCP-independent signaling pathway (Sisson et al., 2015) and increases chondrogenic cell proliferation via Wls and Fgf3 (Wu et al., 2015). WNT5B activates mesenchymal chondroprogenitor cell migration in a JNK-dependent manner (WNT-PCP signaling pathway). In addition, WNT5B decreases cell aggregation and prevents chondrocyte hypertrophy by reducing cadherin expression and destabilizing cadherin receptors via Src-mediated phosphorylation of membranebound $\beta$-catenin. Notably, phosphorylation of $\beta$-catenin by
WNT5B results in decreased membrane-associated $\beta$-catenin and increased nuclear $\beta$-catenin, thereby activating $\beta$-catenin's transcriptional activity (Bradley and Drissi, 2011), in contrast to inhibition of $\beta$-catenin signaling by WNT5B observed in osteoblasts, adipocytes, lung and other tissues (see below).

Although WNT5A and WNT5B both delay chondrocyte differentiation (Yang et al., 2003), their roles are distinct. WNT5A is expressed in joints and in the perichondrium, which is considered Zone I (Church et al., 2002). WNT5A inhibits proliferation and the transition from Zone I to Zone II by repressing Ccnd1, Sox9 and Col2a1 and elevating p130. Meanwhile, WNT5A promotes the transition from Zone II to the pre-hypertrophic zone, which will develop into the hypertrophic zone (Yang et al., 2003; Figure 2). Misexpression of Wnt5a results in truncated limbs and fused joints (Church et al., 2002), 
supporting the positive effect of WNT5A on hypertrophy and long bone formation.

\section{Osteoblasts}

In osteoblast lineage cells, WNT5A and WNT5B exhibit redundant effects in mesodermal progenitor cells (MPCs), which have mesenchymal and endothelial differentiation potential (Petrini et al., 2009). WNT5A and WNT5B activate MPCs from quiescence and induce mesenchymal differentiation to MSCs through the FZD1/Calmodulin signaling pathway. The levels of WNT5A and WNT5B are high when the proliferation rate is low (early MSCs) and then decrease during exponential growth (late MSCs) (Fazzi et al., 2011). Then WNT5A and WNT5B expression increases during osteoblast differentiation (Hurson et al., 2007; Rauner et al., 2008; Okamoto et al., 2014), but the effects of WNT5A and WNT5B are divergent when MSCs commit to being osteoblasts. WNT5A promotes osteoblastogenesis by upregulation of $L r p 5 / 6$ expression and results in enhanced $\beta$-catenin dependent signaling (Okamoto et al., 2014). Osteoblast lineage-specific Wnt5a conditional knockout mice show impaired osteoblastogenesis and decreased trabecular bone volume (Maeda et al., 2012). In contrast, there is some preliminary indication that WNT5B suppresses osteoblast differentiation (Figure 2). High expression of WNT5B, due to the regulation of circular RNA CDR1as, reduces $\beta$-catenin levels leading to decreased osteoblastogenesis in bone marrow mesenchymal stem cells (BMSCs) from steroidinduced osteonecrosis (Chen et al., 2020). However, the direct effects of WNT5B on normal osteoblast differentiation have not been studied.

Mechanical loading regulates bone remodeling by stimulating bone formation directly. Osteocytes, which contain sensors of strain energy, secrete sclerostin to inhibit WNT/ $\beta$-catenindependent signaling, resulting in suppressed osteoblastogenesis in mechanical unloading conditions (Robling and Turner, 2009). The effects of mechanical loading on WNT5A and WNT5B were shown in osteoblast progenitors but have never been tested in osteocytes. Cyclic tension strain elevated WNT5A and WNT5B in BMSCs and MSCs from osteoporotic donors, respectively (Charoenpanich et al., 2014; Gu et al., 2018). In rat tendonderived stem cells, uniaxial mechanical tension (UMT) activates osteoblast differentiation and upregulates WNT5A, WNT5B, ROR2 and RAC1, then WNT5A and WNT5B promote UMTinduced osteoblastogenesis via the activation of JNK (Liu X. et al., 2015). WNT5A also induces osteoblast differentiation from BMSCs through FZD4/JNK signaling under mechanical stimulation ( $\mathrm{Gu}$ et al., 2018). Notably, the distinct actions of WNT5B, but not WNT5A, between normal and mechanical loading-induced osteoblast differentiation demonstrate that WNT5B can act differently in varied conditions.

Bone and teeth both have a mineralized extracellular matrix and have similar properties of differentiation. Ten WNT ligands are expressed in the dental epithelium and mesenchyme during mouse tooth development. Wnt5b is specifically expressed in the papilla mesenchyme of mouse incisors at E16 and E18 (Suomalainen and Thesleff, 2010). Mechanical forces (hydrostatic pressure) upregulate expression of WNT5B in human exfoliated deciduous teeth stem cells and activate odontoblast differentiation (Miyazaki et al., 2019), similar to what is observed after mechanical forces in rat tendon-derived stem cells (Liu X. et al., 2015).

Bone fracture healing requires several steps and signaling pathways to regenerate new bone (Marsell and Einhorn, 2011). Indirect suppression of WNT5B and $\beta$-catenin via miRNAs that target parathyroid hormone (Yao et al., 2018) and PANX3 (Jia and Zhou, 2018) results in inhibition of fracture healing. Moreover, knockout of Toll-like receptor 4 (TLR4), which inhibits the $\mathrm{WNT} / \beta$-catenin signaling pathway, promotes fracture healing and increases $\beta$-catenin, WNT4, WNT5B, PCNA, and BMP-2 (Zhao et al., 2020), suggesting that $\beta$-catenin and WNT5B play similar roles in bone fracture healing. As both WNT/ $\beta$-catenindependent and independent signaling pathways are involved in specific generative patterns of bone repair (Heilmann et al., 2013; Houschyar et al., 2018), WNT5B might regulate $\beta$-catenin activities to generate new bone. Nevertheless, the mechanisms that link WNT5B and $\beta$-catenin in this process are not understood.

\section{Osteoclasts}

WNT5A and WNT5B are expressed in the osteoclast lineage and promote bone resorption by enhancing osteoclast differentiation (Figure 2). Nevertheless, their mechanisms of action are dissimilar. WNT5B increases TRAP activity through the RYK receptor and suppresses $\beta$-catenin signaling in osteoclasts (Santiago et al., 2012). Meanwhile, WNT5A is highly expressed, secreted from osteoblast lineage cells and increases osteoclastogenesis by upregulating receptor activator of nuclear factor-kB (RANK) in bone marrow macrophages (BMMs), which are osteoclast precursors, via the ROR2/JNK non-canonical signaling pathway (Maeda et al., 2012). Notably, the expression of the receptors RYK and ROR2 in osteoclast lineages differs between the Maeda et al. (2012) and Santiago et al. (2012) studies. RT-PCR shows that RYK is highly expressed in both undifferentiated and differentiated murine osteoclast precursor monocytic cells (RAW264.7), while ROR2 is less expressed, and knockdown of the RYK receptor abolishes the effect of WNT5B (Santiago et al., 2012), supporting the argument that WNT5B signals through RYK signaling. In contrast, Maeda et al. (2012) found that ROR2 is in BMMs and conditional knockout of Ror2 in RANK-expressing cells prevents WNT5Ainduced osteoclastogenesis. The two contrasting results may be due to using an in vitro vs. an in vivo system. Thus, further work will be required to determine the role of WNT5B in the differentiation and activity of osteoclasts.

\section{Bone Diseases}

Osteoarthritis $(\mathrm{OA})$ is a common age-dependent degenerative joint disease found in women more frequently than men. It is characterized by progressive degeneration of the components of extracellular matrix (ECM) of the articular cartilage and subchondral bone associated with secondary inflammatory factors (Dijkgraaf et al., 1995). Loss of the canonical WNT signaling pathway can be observed in OA pathogenesis. The specific knockout of $\beta$-catenin (Ctnnb1) at the superficial zone 
promotes OA development (Xuan et al., 2019) and $\beta$-catenin is decreased in OA, while p-JNK, p-CaMKII and p-PKC are increased (Huang et al., 2020). WNT5B is upregulated in OA patients (Hopwood et al., 2007; Shi and Ren, 2020) and has higher expression in trabecular bone from women compared to men (Hopwood et al., 2007), indicating that it is a candidate to stimulate OA progression. WNT5B activates synovial MSC (SMSC) proliferation and migration via the Hippo-YAP signaling pathway (Tao S.C. et al., 2017). However, WNT5B inhibits chondrocyte differentiation and ECM secretion as well as promotes fibrosis by increasing collagen type I secretion (Tao S.C. et al., 2017; Huang et al., 2020), leading to joint degeneration. For inflammatory-induced OA, lipopolysaccharide activates WNT5B expression in human chondrocyte cells (CHON-001 cells) (Shi and Ren, 2020). WNT5B expression correlates with TGF- $\beta 1$, a key player in OA pathology, in osteoblasts from OA patients (Kumarasinghe et al., 2012). WNT5B also increased MMP13 expression in SMSCs, which may lead to joint degradation (Huang et al., 2020).

WNT5A is also elevated in OA patients (Martineau et al., 2017) and shows similar effects on SMSC proliferation and migration as WNT5B (Tao S.C. et al., 2017). Nevertheless, the inhibition of WNT5A on SMSC differentiation to chondrocytes is different from WNT5B. WNT5A aggravates joint degeneration by inducing senescence and inflammatory cytokines such as IL$1 \beta$ and IL-6 in SMSCs, whereas WNT5B does not (Huang et al., 2020). Taken together, WNT5A and WNT5B are involved in OA pathogenesis but the mechanisms of action are different.

Osteoporosis is a bone metabolic disorder in which there is a loss of BMD due to an imbalance between bone formation and bone resorption, leading to an increased risk of bone fractures (Imel et al., 2014). The effect of WNT5B on osteoporosis is still unclear due to the lack of research on WNT5B in normal bone cells. However, several genetic studies link single nucleotide polymorphisms (SNPs) near WNT5B to osteoporosis. In 2012, a genome-wide meta-analysis first reported that WNT5B might affect BMD through SNP rs2887571 (Figure 3; Estrada et al., 2012). rs 2887571 is correlated with BMD in children, and children carrying the risk allele at rs2887571 benefited from physical activity (Mitchell et al., 2016). However, since rs2887571 is located in a non-coding intergenic region, the true target gene or consequence of the polymorphism is still unknown. Other SNPs in the WNT5B gene (rs2240506, rs7308793, rs4765830, and rs735890) are also associated with BMD (Zheng et al., 2016). Interestingly, SNP rs735890 in WNT5B disrupts mRNA secondary structure and dictates the binding of miRNA, resulting in less translation of WNT5B and increased BMD (AmjadiMoheb et al., 2018). The molecular mechanisms of how WNT5B is influenced by these SNPs should be further investigated.

\section{ROLE OF WNT5B IN ADIPOSE TISSUE}

WNT5B has been shown to both transiently increase (Kanazawa et al., 2005) and decrease in early adipogenesis. However, both studies demonstrated that WNT5B activates adipocyte differentiation by elevating the level of adipocyte markers, such as peroxisome proliferator-activated receptor- $\gamma(\operatorname{PPAR} \gamma), \mathrm{C} / \mathrm{EBP} \alpha$, AP2, Adiponectin and Leptin (Kanazawa et al., 2004; van Tienen et al., 2009). Furthermore, WNT5B abolishes the effect of WNT3A-suppressed adipogenesis (Kanazawa et al., 2005) by inhibiting $\beta$-catenin nuclear translocation and suppressing canonical WNT targeted genes such as IGF-1, WISP-1, and VEGF-C (Kanazawa et al., 2005; van Tienen et al., 2009). Conversely, WNT5A inhibits adipogenesis. Wnt5a-/- mice have an increased number of adipocytes (Maeda et al., 2012) and WNT5A suppresses adipocyte differentiation from rat adipose-derived stem cells in vitro (Tang et al., 2018). This demonstrates the opposite effects of WNT5A and WNT5B in adipocytes, as well as in chondrocytes and osteoblasts, all of which originate from MSCs.

\section{ROLE OF WNT5B IN THE PANCREAS}

WNT5B and WNT5A are expressed in embryonic mesenchyme where $\beta$-cells differentiate during mouse pancreatic development. WNT5B is strongly upregulated and localizes around insulinand glucagon-immunoreactive cells; WNT5A, in contrast, has less expression and low localization with these cells (Heller et al., 2002). WNT5A increases ROR2 on the cell membrane, while WNT5B elevates the level of c-JUN, the downstream signaling of JNK (Vethe et al., 2019), suggesting that WNT5A and WNT5B act through the $\beta$-catenin-independent signaling pathway in pancreatic $\beta$-cells. In this study, the receptor for WNT5B was not analyzed, nor was the receptor for WNT5A, beyond the observation of increased ROR2 on the cell membrane. WNT5A and WNT5B together were shown to increase differentiation of $\beta$-like cells from induced pluripotent stem cells. In addition, WNT5A together with WNT5B or WNT5B alone, but not WNT5A alone, increase the level of NKX6.1, a transcription factor that controls $\beta$-cells fate, identity and function (Schaffer et al., 2013; Taylor et al., 2013), in human induced pluripotent stem cells differentiated to $\beta$-like cells (Vethe et al., 2019).

\section{ROLE OF WNT5B IN TYPE 2 DIABETES MELLITUS}

A case-control association study showed that SNP rs2270031, located in a WNT5B intron (Figure 3), is strongly associated with type 2 diabetes mellitus (T2DM) in a Japanese population (Kanazawa et al., 2004). In addition, a study in a UK population combined rs2270031 with rs7903146 (located in an intron of TCF7L2, a transcription factor for glucagon-like peptide-1), to show a risk effect for T2DM (Salpea et al., 2009). The necessity to combine the two genes to show an effect might be due to the fact that Caucasian subjects rarely have the risk allele at rs2270031. WNT5B regulates both adipocytes and pancreatic cells, two main cell types affected in diabetes, and mis-regulation of WNT5B via this SNP or otherwise in these cell types may lead to disease. Therefore, the effects of WNT5B in T2DM need further investigation. 


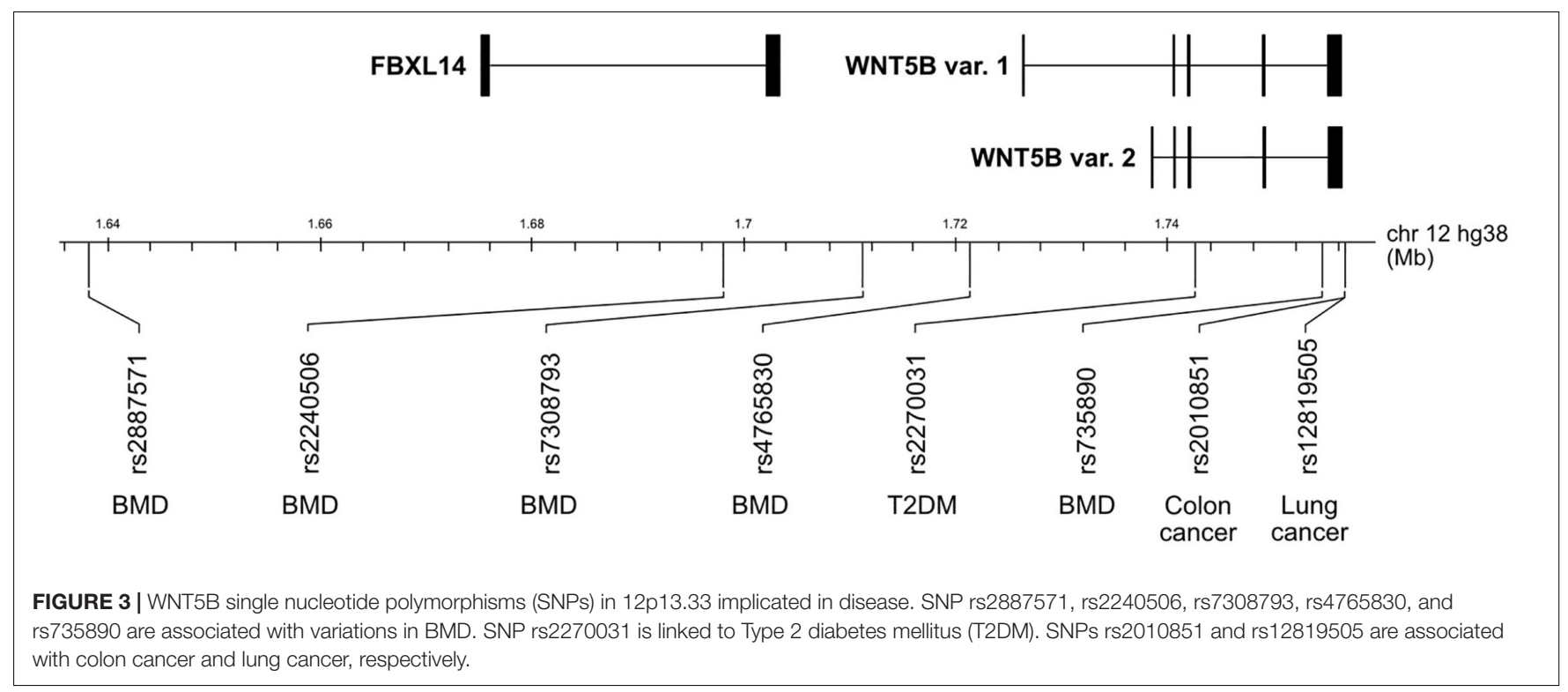

\section{ROLE OF WNT5B IN CARDIAC TISSUE}

WNT5A and WNT5B are expressed at various stages of heart development. They direct the commitment of mesoderm to cardiogenic mesoderm by elevating MESP1, the earliest cardiogenic marker, via the ROR2/JNK WNT signaling pathway (Mazzotta et al., 2016). WNT5A and WNT5B also stimulate the differentiation of cardiomyocytes via FZD4/6/Ca ${ }^{2+}$ WNT signaling pathway in late development (Mazzotta et al., 2016). However, only WNT5B promotes pacemaker cardiomyocytes, which are essential for the initiation and maintenance of proper heart rhythm through the activation of the canonical $\beta$-catenin/WNT signaling pathway (Ren et al., 2019). Interestingly, activation of the canonical pathway by WNT5B is observed here, as it is in chondrocytes, but in contrast to inhibition of $\beta$-catenin signaling by WNT5B observed in osteoblasts, adipocytes, lung and other tissues.

Aortic valve calcification causes aortic valve stenosis, which induces heart failure. WNT5A and WNT5B show the same effects on calcification development. Their expression is significantly, positively correlated with pathological calcified valves. WNT5A and WNT5B reduce proliferation and induce apoptosis of human aortic valve interstitial cells, increase osteogenic gene expression and increase calcium deposition and formation in calcified nodules via the JNK/Akt1/MAPK38 signaling pathway (Albanese et al., 2017). Fetuin A, a calcification inhibitor, reduces the expression of WNT5A and WNT5B (Khan et al., 2020).

\section{ROLE OF WNT5B IN THE NERVOUS SYSTEM}

WNT5B is moderately expressed in the human and zebrafish fetal brain, especially in midbrain-hindbrain boundary constriction in zebrafish and is required for basal constriction via activation of focal adhesion kinase (FAK) (Gutzman et al., 2018). Then its expression decreases in adulthood (Saitoh and Katoh, 2001) similar to WNT5A (Gavin et al., 1990). The effects of WNT5A and WNT5B are both different and redundant in the nervous system, depending on cell types and contexts. Neural stem cells (NSCs) have the capacity to differentiate into either neurons, astrocytes or oligodendrocytes in the central nervous system (CNS). Wnt5b is increased more than twofold, while Wnt5a is only slightly elevated, in differentiated cells compared to NSCs (Choi et al., 2011). The median motor column (MMC) contains a set of motor neurons arranged in a longitudinal array and innervates axial muscles. WNT5B and WNT5A redundantly control MMC identity and connectivity by establishing a ventral ${ }^{\text {high }}$ to dorsal ${ }^{\text {low }}$ signaling gradient, subsequently promoting the persistent expression of LIM Homeobox protein 3 and 4, the transcription factors for cell specification (Agalliu et al., 2009).

WNT5B is also required for the mechanosensory system in mammalian and lower vertebrates. In zebrafish (Danio rerio), WNT5B regulates ciliogenesis in the inner ear and migration of neuromasts to the lateral line, a sensory organ of fishes, through the RGS18-mediated WNT- $\mathrm{Ca}^{2+}$ signaling pathway, whereas WNT5A does not have any effect on cilia-mediated mechanosensory cells (Louwette et al., 2012). In the juvenile rat cochlea, WNT5B is expressed in non-sensory supporting cells, and more strongly expressed in fibrocytes of the spiral limbus and spiral ligament (Daudet et al., 2002). This suggests a function of WNT5B in late cochlea differentiation, as well as auditory function, although no functional experiments have been performed to date.

WNT5B and WNT5A have the same effects on the development and degradation of retinal and optic nerves. Both proteins regulate retinal neuropil formation in the outer retina. WNT5A and WNT5B are selectively secreted by rod bipolar cells to rod photoreceptors, and then control the patterning of the outer plexiform layer via the RYK/FZD4/FZD5/DVL 
signaling pathway (Sarin et al., 2018). WNT5A and WNT5B are also elevated in a mouse model of retinal degradation (Yi et al., 2007), suggesting that they function during photoreceptor injury. However, the mechanism of action requires further investigation. Moreover, WNT5A and WNT5B are expressed in the neural retina, but not in retinal pigment epithelium (RPE) in the mouse embryo (Liu et al., 2003). A study in human embryonic stem cell-derived RPE cells supported that WNT5B and its downstream signaling have to be suppressed, while high expression of BMP7 is required in order to successfully go through epithelialization of the RPE cells (Choudhary et al., 2015).

WNT5B also controls optic nerve regeneration in lower vertebrates. Axon growth in zebrafish requires the activation of small G-proteins, such as CDC42 and Rac1, whereas RhoA has to be suppressed. Wnt5b is increased, while Wnt10a is decreased and Wnt5a has no change, after optic nerve transection. WNT5B stimulates the CDC42/Rac1/JNK/PAK signaling pathway and represses RhoA via $\mathrm{CDC} 42$, together with the reduction of $\beta$-catenin level in the nucleus due to the decrease of WNT10A. Both of these actions lead to axon extension (Matsukawa et al., 2018).

The expression of WNT5B is affected in several nerve injuries and neuropathology. Morphine treatment induces WNT5B accumulation in the dorsal ganglia root (DRG) and it is exported to the central terminus of the spinal cord dorsal horn (DH) after morphine withdrawal. Translocated WNT5B at the DH then increases $\mathrm{Ca}^{2+}$ influx via RYK, resulting in behavioral and neurochemical alteration of morphine withdrawal. Meanwhile, the level of Wnt5a expression is decreased after morphine treatment and morphine withdrawal (Wu et al., 2020). Chronic constriction injury-induced neuropathic pain and complete Freund's adjuvant-induced chronic inflammation also elevate the level of Wnt5b expression in the DRG. Notably, the expression level of $R y k$ is raised in the same pattern as $W n t 5 b$ and a RYK antagonist abolishes the effects of the WNT/RYK/CaMKII/NR2B signaling pathway in neurons (Liu S. et al., 2015; Wu et al., 2020). However, there is no direct investigation of the effect of WNT5B on nerve injury. In addition, epilepsy is neural network remodeling in the hippocampus dentate gyrus, which associates with the alteration of WNT signaling pathways. WNT5B is significantly dysregulated between the ictal zone and peri-ictal zone, the center and remodeling network region after seizure induction, respectively. In contrast, $W n t 5 a$ is downregulated in both regions (Gupta and Schnell, 2019). Nevertheless, the mechanisms of action of WNT5B in epilepsy are poorly understood. Lastly, an epigenome-wide association study revealed that alteration in DNA methylation at the first intron of the longest isoform of WNT5B is associated with Alzheimer's disease progression (Smith et al., 2019). However, the consequences of the methylation and different isoform functions remain unknown.

Together, these data suggest that WNT5B has varied expression in both the CNS and the peripheral nervous system, and exhibits several roles during embryonic development and pathogenesis, such as in neuron identity and patterning, neuron regeneration, and the mechanosensory system.

\section{ROLE OF WNT5B IN THE MAMMARY GLAND}

Wnt5a and $W n t 5 b$ are expressed in the more differentiated luminal epithelial cells of the mammary gland (Ji et al., 2011). Wnt5b is also expressed in the mammary gland during mid-pregnancy and disappears in lactation, while Wnt5a is expressed in early pregnancy (Gavin and McMahon, 1992). In the mammary gland WNT5B signals through ROR2 and RYK-independent receptors. WNT5B inhibits mammosphere formation by downregulating proliferation genes, such as $\mathrm{Mcm} 2$ and Ki67, as well as luminal differentiation genes, such as Gata3. WNT5A, in contrast, increases the number and size of mammospheres via the RYK receptor, and suppresses mammary gland branching via the ROR2 receptor (Kessenbrock et al., 2017), whereas WNT5B does not have any effect on mammary gland branching. These data, again, suggest distinct roles of WNT5A and WNT5B. Further work on the role of WNT5B in the mammary gland should be performed, as there are numerous reports of WNT5B in breast cancer (see below).

\section{ROLE OF WNT5B IN THE LUNG}

Both WNT5A and WNT5B are expressed in the lung and have been implicated in lung pathogenesis, including COPD and lung cancer. WNT5A and WNT5B are secreted from lung fibroblasts in a paracrine manner to inhibit alveolar epithelial progenitors, while inducing epithelial differentiation. WNT5B, but not WNT5A, induces expression of Aquaporin 5 (Aqp5, a marker for alveolar type I cells) and Surfactant protein C (Sftpc, a marker for alveolar epithelial type II cells). WNT5B also shows a stronger repressive effect on alveolar organoid formation compared to WNT5A. However, canonical WNT/ $\beta$-catenin signaling is repressed by both WNT5A and WNT5B in these cells. WNT5A and WNT5B seem to have similar functions, but are not identical (Wu et al., 2019).

Chronic obstructive pulmonary disease (COPD) is caused by defective epithelial lung repair associated with an abnormal inflammatory response. Alteration of fibroblast functions also plays an important role in COPD pathogenesis. WNT5B has higher expression in COPD patients (Heijink et al., 2016), suggesting a role in its pathogenesis. Furthermore, TGF- $\beta 1$, a key player in fibroblast activation to repair lung injury, increases WNT5B expression and then WNT5B stimulates ECM production (fibronectin and $\alpha$-smooth-muscle actin) and myofibroblast differentiation via FZD8 (Spanjer et al., 2016). WNT5B induces an inflammatory response in MRC-5 human fibroblasts and primary human lung fibroblasts by increasing IL-6 and CXCL8 secretion via the FZD2/Tak1/JNK signaling pathway (van Dijk et al., 2016). WNT5A is also highly expressed and impairs lung repair in COPD patients through the WNT/ $\beta$-catenin-independent signaling pathway (Baarsma et al., 2017). These studies indicate that non-canonical WNT5A and WNT5B have similar roles in the lung and activating the development of COPD. 


\section{ROLE OF WNT5B IN HEMATOPOIESIS}

Hematopoietic stem cells (HSCs) generate the balance between lymphoid and myeloid cell types which impact immunity efficiency and tissue homeostasis. WNT5B is expressed in HSCs (de Rezende et al., 2020) and has been reported in the development of myeloid and lymphoid lineage cells.

Acceleration of myelopoiesis in the elderly contributes to the development of chronic diseases associated with aging. Primitive cells such as HSCs and multipotent progenitors are more sensitive to IL-3, which supports stem cell maintenance, while committed myeloid progenitors are more sensitive to Granulocyte-Macrophage-Colony Stimulating Factor (GMCSF), which drives differentiation and proliferation. WNT5B exhibits divergent effects on IL-3 and GM-CSF-induced myeloid differentiation, which relate to aging-associated myeloid imbalance. WNT5B enhances HSCs and progenitors by suppressing IL-3-mediated myeloid differentiation and noncanonical WNT signaling genes such as c-Fos, c-Jun, and Cdc42. Meanwhile, WNT5B accelerates GM-CSF-driven myelopoiesis and upregulates non-canonical WNT signaling genes, leading to progenitor cell exhaustion. Notably, osteoclasts are derived from the monocyte/macrophage lineage and WNT5B may play a role in osteoclast progenitor cells to affect bone mass. Furthermore, WNT5B controls megakaryocyte differentiation through RGS18 as depletion of Wnt5b in zebrafish embryo shows severe thrombopenia (Louwette et al., 2012). Interestingly, $W n t 5 a$ is expressed in primitive HSCs and niche cells, as is Wnt5b, but WNT5A does not affect IL-3- and GM-CSF-induced HSC differentiation (de Rezende et al., 2020).

The primary lymphoid organ for T-cell development is the thymus. The thymus functions to ensure that T-cells are selected to prevent autoimmunity. The T-cell section for nonautoimmune T-cells is mediated by both distinct thymic stromal cells and cortical and medullary epithelial cells (Anderson and Jenkinson, 2001). The full maturation of thymic epithelial cells (TECs) occurs in the third pharyngeal pouch (ppIII) of the thymus. Growth and development of TECs (Anderson and Jenkinson, 2001) are dependent on Forkhead Box N1 (FoxN1) expression, and in its absence, epithelial morphogenesis in the thymus is aberrant. These epithelial cells lack the ability to attract lymphoid precursors to the thymus primordium. Wnt5b expression is found in thymocytes, peripheral $\mathrm{T}$ cells and epithelial cells. Meanwhile, $W n t 5 a$ has no expression in these cells. Interestingly, Wnt5b is highly expressed in $\mathrm{CD}^{+} \mathrm{CD}^{+}$ double-positive thymocytes and decreases by $75-95 \%$ during later stages of $\mathrm{T}$ cell development. Moreover, the transduction of cortical TEC 1-2 cells with Wnt5b upregulates FoxN1 and WNT5B is strictly localized with FoxN1 in ppIII. This suggests that WNT5B is involved in lymphocyte differentiation by regulating FoxN1 (Balciunaite et al., 2002), but the mechanism of WNT5B on T cells is still poorly understood. In addition, WNT5B also contributes to a dysregulated immune response and the production of inflammatory cytokines to the infection. WNT5B, but not WNT5A, increases in whole blood from patients with septic shock and directly correlates with IL-6, IL-10, and TNF (Gatica-Andrades et al., 2017).

\section{ROLE OF WNT5B IN THE LYMPHATIC SYSTEM}

The lymphatic system origins have had two opposing models for close to 100 years, one suggests a venous origin for lymphatic endothelial cells, and the other a more random coalescence of discontinuous, independent lymphatic vessels arising from mesenchymal-derived cells. A study in zebrafish demonstrated that lymphatic progenitor cells, which arise from a specialized angioblast within the cardinal vein that can also give rise to arterial veins, are governed by WNT5B activity (Nicenboim et al., 2015). WNT5B is necessary and sufficient for lymphatic endothelial specification. WNT5B promoted the angioblast to lymphatic transition in both zebrafish and human embryonic stem cells, suggesting this function by WNT5B is evolutionarily conserved. WNT5B has also been shown to be secreted from tumor cells to induce tumor lymphangiogenesis (Wang et al., 2017). WNT5B enhanced the lymph vessel formation, permeability and migration of lymphatic endothelial cells. These findings can potentially lead to the development of regeneration of lymphatic vessels for human usage or inhibition of lymphangiogenesis in cancer.

WNT5A also increased migration of lymphatic endothelial cells, leading to elongated tube formation. This was demonstrated in mice, using the dermal lymphatic vascular system, and not compared to WNT5B in the same system (Lutze et al., 2019).

\section{ROLE OF WNT5B IN CANCER}

\section{Breast Cancer}

WNT1 was originally identified due to its ability to transform mammary gland cells. WNT2, WNT3A, WNT7A, WNT7B, WNT10B, and WNT5B are also highly transforming of mouse mammary cells. In contrast, WNT5A (and WNT4 and WNT6) failed to induce transformation (Wong et al., 1994).

$W N T 5 B$ is overexpressed in the majority of Triple Negative (TNBC)/Basal-Like Breast Cancer (BLBC) cell lines and primary patient samples and is correlated with a worse prognosis (Yang et al., 2014; Jiang et al., 2019). In addition, WNT5B was found to be amplified in $3.2 \%$ of breast cancers, although the type of breast cancer with WNT5B amplification was not described (Jiang et al., 2019). Knockdown of WNT5B inhibited the proliferation, migration and invasion of Bcap-37 and MDAMB-231 cells in vitro and reduced the expression of basal-like markers (Yang et al., 2014; Jiang et al., 2019). Mechanistically, WNT5B was shown to promote TAZ activation by promoting the transcription of SLUG, which is a master regulator of epithelial-mesenchymal transition (EMT) as well as a regulator of TAZ nuclear localization and subsequent activation (Samanta et al., 2018). In addition, knockdown of WNT5B in MDAMB-231 and Bcap-37 cells showed reduced tumor growth in BALB/c-nu mice compared with control cells. Targeting WNT5B (and all WNTs) through the addition of WNT inhibitors pyrvinium pamoate (a CK1 $\alpha$ activator) or LGK-974 (a Porcupine inhibitor) also reduced tumor growth and proliferation in vivo (Jiang et al., 2019). 
The regulation of WNT5B expression in breast cancer (or other cell types) is not well-studied. However, it was shown that WNT5B is suppressed by miR145-5p in three basal-like breast cancer cell lines. Mechanistically, insulin-like growth factor2 mRNA-binding protein 3 (IMP3), which is correlated with TNBC, stabilizes WNT5B by suppressing miR145-5p.

WNT5A and WNT5B also have different roles in mammary gland development and TNBC. In contrast to WNT5B, many publications show WNT5A as a tumor suppressor in breast cancer, correlating its loss with a worse prognosis (Zeng et al., 2016). However, the opposite has also been shown: WNT5A is higher in breast carcinomas and induces tumorigenicity in breast cancer (Iozzo et al., 1995; Zeng et al., 2016). Therefore, the roles of WNT5A and WNT5B in breast cancer need further research.

\section{Pancreatic Cancer}

Genomic analysis of pancreatic ductal carcinoma revealed four major subtypes (Bailey et al., 2016) and the WNT signaling pathway was found to be enriched in the squamous subtype, which is the most aggressive subtype. Specifically, overexpression of canonical WNT ligands such as WNT2 and WNT7A has been implicated in pancreatic progression via persistent activation of $\beta$-catenin signaling. In addition, the non-canonical WNT ligand WNT5A has been shown to lead to pancreatic cancer progression and chemoresistance (Wei et al., 2014; Bo et al., 2016; Ram Makena et al., 2019).

Only a few studies have suggested roles for WNT5B in normal or cancerous pancreatic cells. Although WNT5B has not been studied in pancreatic cancer patient samples, WNT5B mRNA is highly expressed in the pancreatic cancer cell line PANC1 (Harada et al., 2017). Panc-1 cancer cells (and the lung adenocarcinoma cell line A549) can induce the invasive ability of neighboring epithelial cells both in vitro and in vivo. WNT3 and WNT5B are secreted from mesenchymal-transitioned cancer cells to induce the metastatic potential of neighboring epithelial cells (Kato et al., 2014). Knockout of WNT5B in Panc-1 cells reduced migration and invasion, but not proliferation. In control PANC-1 cells, addition of TGF- $\beta$ increased the expression of Snail and Vimentin mRNA and decreased E-cadherin. However, in WNT5B knockout cells, TGF- $\beta$-dependent increases of Snail and Vimentin mRNA were reduced and the expression of $E$ cadherin mRNA decreased. These results suggest that WNT5B may be involved in TGF- $\beta$-induced EMT (Harada et al., 2017).

WNT5B has also been shown to be secreted in exosomes from PANC-1 cells. WNT5B-associated exosomes promoted cancer progression in a paracrine manner, as seen in their ability to induce proliferation and migration on A549 lung cancer cells (Harada et al., 2017). The contribution of WNT5B in exosomes vs. secretion needs to be explored in both pancreatic cancer and other cell types.

\section{Lung Cancer}

Many WNT ligands, both canonical and non-canonical, and WNT signaling proteins are misregulated in lung cancer. Specifically, both WNT5A and WNT5B are overexpressed in non-small cell lung cancers (NSCLC) compared to normal tissue and their overexpression is correlated with poor overall survival (Huang et al., 2005; Zhang et al., 2020). Knockdown of $W N T 5 B$ reduced the proliferation and growth rate of lung adenocarcinoma both in vitro and in vivo by inducing cell-cycle arrest at the G1/S phase. Mechanistically, WNT5B was shown to regulate the metabolism of the lung cancer cells, including the amino acid transporter LAT1. In addition, miR-5587-3p was shown to repress WNT5B in these cells (Zhang et al., 2020).

In a group of non-small cell lung carcinomas, variants for rs12819505 (Figure 3) were significantly associated with worse prognosis (Stewart et al., 2014). The function of this SNP, which is a few hundred base pairs downstream of the WNT5B coding sequence is unknown.

\section{Colorectal Cancer}

WNT signaling is highly important in colorectal cancer (CRC) through the regulation of proliferation, differentiation, and cell fate. WNT signaling is activated in normal intestinal crypts, which is crucial for stem cell maintenance and tissue homeostasis. The canonical WNT/ $\beta$-catenin pathway is constitutively activated in more than $90 \%$ of colorectal cancers. APC suppresses $\beta$-catenin-mediated WNT signaling and is thus a tumor suppressor gene. Germline mutations in APC lead to familial adenomatous polyposis (FAP) and account for about 1$2 \%$ of CRC. Somatic mutations in APC have also been found in a majority of sporadic CRC (Aoki and Taketo, 2007).

In contrast to $\beta$-catenin-dependent signaling, very little is known about WNT5B in CRC. At least five CRC cell lines express WNT5B and the addition of WNT5B to COLO 205 cells promoted cell proliferation, migration and invasion through the JNK signaling pathway (Zhang et al., 2016). Examination of patient samples for mRNA and/or protein levels could determine if there is a role for WNT5B in CRC.

The polymorphism rs2010851 in the $3^{\prime}$ UTR of WNT5B (Figure 3) was shown to predict tumor recurrence in stage II colon cancer. This specific WNT5B SNP is significant because it shows for the first time that a WNT polymorphism can predict early tumor recurrence in colorectal cancer (Paez et al., 2014), and suggests that more research needs to be done to understand the consequences of both the SNP and WNT5B in CRC.

Similarly, the role of WNT5A in CRC is not clear, as WNT5A has both been shown to promote migration and invasion (Bakker et al., 2013) and to inhibit cell proliferation and EMT (Cheng et al., 2014). WNT5A is down-regulated in a majority of colon cancers and suppressed during colon cancer metastasis (Li and Chen, 2012; Tao J. et al., 2017). The contradictory roles of WNT5A in CRC could be due to two different WNT5A splice forms, with each form having opposing functions (Huang et al., 2017).

\section{Oral Squamous Cell Carcinoma}

Expression profiles from 40 patients with oral squamous cell carcinoma (OSCC) revealed a small (1.5-fold) increase in WNT5B mRNA in $40 \%$ of cases. In addition, WNT5B mRNA and protein were higher in patients with nodal metastases (Wang et al., 2017). As in many other cancer types, knockdown of WNT5B decreased OSCC cell line proliferation and migration (Takeshita et al., 2014; Wang et al., 2017). WNT5B was further 
shown to activate CDC42 and RhoA, which are involved in cell migration (Takeshita et al., 2014). In the HSC-4 OSCC cell line, TGF- $\beta 1$ stimulated Slug which increased WNT5B expression, while decreasing WNT5A expression. In turn, WNT5B increased the expression of MMP-10, a matrix metalloproteinase that induces tumor progression and invasion (Hino et al., 2016).

\section{Osteosarcoma}

Osteosarcoma is a cancer that starts in the bone, and affects mostly children, especially during puberty. In osteosarcoma, it has been identified that the interaction of WNT5B and ROR2 can enhance cell migration, which supports a potential role of ROR2 and WNT5B in the metastatic pathway of osteosarcoma cells. ROR 2 was overexpressed in $56 \%$ of patient samples and the expression pattern of WNT5B expression is concurrent with that for ROR2. Knockdown of ROR2 suppressed proliferation and invasion of osteosarcoma cells, suggesting that ROR2 and WNT5B could be promising therapeutic targets for osteosarcoma patients (Morioka et al., 2009).

While only one paper exists on the significance of WNT5B in osteosarcoma, several highlight the importance of WNT5A. WNT5A was overexpressed in $81 \%$ of 42 osteosarcoma immunohistochemistry samples and was significantly correlated with advanced surgical stage and tumor metastasis ( $\mathrm{Lu}$ et al., 2012). Specifically, WNT5A increased migration and invasion of osteosarcoma cell lines (Enomoto et al., 2009; Wang et al., 2018). As in CRC, the different isoforms of WNT5A have different roles in osteosarcoma cell lines (Vaidya et al., 2016). WNT5B also has two different promoters and splice forms, suggesting the need to also investigate WNT5B isoforms in osteosarcoma.

\section{Ovarian Cancer}

WNT5B is important in ovarian cancer, particularly in ovarian cancer stem cells (OCSC). Immune cells, including macrophages, are enriched in ovarian cancer ascites. Raghavan et al. (2019) demonstrated that WNT5B from macrophages induces expression of the stem cell marker $A L D H$ in the OCSC in a paracrine manner. They also showed a $50 \%$ decrease in $\beta$-catenin protein expression after WNT5B knockdown, indicating crosstalk with canonical WNT signaling (Raghavan et al., 2019). Zong et al. (2020) also demonstrated the importance of WNT5B in OCSC and demonstrated that WNT5B induces ALDH expression in OCSC. Their research proposed that the tumor suppressor Disabled homolog 2-interacting protein (DAP2IB) down-regulates WNT5B in OCSC and proposed the pathway in which EZH2 inhibits DAP2IB, which inhibits WNT5B signaling. Addition of recombinant WNT5B to the ovarian cancer cell line OVCAR3 induced JNK and c-Jun phosphorylation and downstream stemness related genes (Zong et al., 2020). They further suggested that combining an EZH2 inhibitor, or other epigenetic therapy, with a non-canonical WNT pathway inhibitor for ovarian cancer would be optimal.

While not much is known about the clinical implications of WNT5B, high expression of WNT5A has been significantly correlated with ovarian cancer stage, poorer overall survival and poorer progression-free survival (Peng et al., 2011). WNT5A has been shown to regulate ovarian cancer invasion and migration.
In addition, it has been shown that WNT5A may mediate vasculogenic mimicry and EMT in ovarian cancer cells via PKC- $\alpha$ signaling (Qi et al., 2014). In contrast, Bitler et al. (2011) propose that loss of WNT5A expression predicts worse outcomes in patients with Epithelial Ovarian Cancer (EOC) and that WNT5A expression suppresses the growth of EOC cells by initiating cellular senescence. While both WNT5B and WNT5A have been shown to be expressed in ovarian cancer, their functions are distinct.

\section{Brain Cancer}

There are more than 120 types of brain and central nervous system tumors. The presence and/or biology of WNT5B in these tumors are mostly unknown. The WNT5B locus has been shown to be amplified in astrocytomas (Schiffman et al., 2010), but this has not been further described. The expression of WNT5B has been shown in gliomas and atypical teratoid rhabdoid tumors (ATRT), but studies beyond gene expression have not been performed. WNT5B expression was correlated with better overall survival, in contrast to patients with elevated WNT5A expression that had overall worse survival (Xu et al., 2020). In a set of ATRT samples, WNT5B was upregulated in 19 of the 20 samples. Furthermore, WNT inhibitors were shown to decrease proliferation in these cells. WNT5B was shown to bind to FZD1 but the functional role of WNT5B in ATRT patients is still unknown (Chakravadhanula et al., 2015).

\section{Hepatocellular Carcinoma}

Hepatocellular carcinoma (HCC) can be divided into welldifferentiated (epithelial, conserved hepatocyte morphology) and poorly differentiated (mesenchymal, more motile and invasive) tumors. A study of HCC cell lines revealed that canonical WNT ligands (WNT3, WNT8B, and WNT10B) are expressed in well-differentiated tumors, while non-canonical WNT ligands such as WNT5B and WNT5A are correlated with poorly differentiated tumors. This study further proposes a potential crosstalk mechanism by which non-canonical WNT5A inhibits canonical WNT signaling (Yuzugullu et al., 2009).

The expression of WNT ligands was also evaluated in 360 HCC tumor tissues and 50 adjacent non-tumor tissues by RNA-sequencing. The expression of five WNT genes (WNT2B, WNT3A, WNT6, WNT8B, and WNT10B) was higher in tumor tissues than adjacent normal cells. Six WNTs, including WNT5B, showed the opposite pattern of expression, suggesting that WNT5B may have anti-tumor activity in HCC. Meanwhile, there was no significant difference in WNT5A expression in tumor and adjacent normal tissue (Dong et al., 2019).

\section{Leukemias}

Several groups have shown that WNT5B is significantly higher in chronic lymphocytic leukemia (CLL) than normal B cells. Specifically, WNT5B is higher in patients without IgV mutations (Lu et al., 2004; Memarian et al., 2009; Janovska et al., 2016). This higher expression of WNT5B correlates with CLL aggressiveness in patients. WNT5A also is highly expressed in CLL and correlates with CLL aggressiveness. However, the signaling induced by WNT5A and WNT5B is not identical, as 
only WNT5A induced DVL3 phosphorylation and only WNT5A correlated with basal migration (Janovska et al., 2016).

WNT5B was also shown to be highly expressed in EpCAM ${ }^{+}$ cells (leukemia stem cells) in acute myeloid leukemia (AML) and to associate with the resistance of $\mathrm{EpCAM}^{\text {high }}$ myeloid leukemia cells to cytotoxic chemotherapy (Zheng et al., 2017). In contrast, WNT5A expression is epigenetically silenced in a majority of patients with AML (Martin et al., 2010).

\section{CONCLUSION}

WNT5B is often assumed to have a similar function as WNT5A because they belong to the WNT5 subfamily and share a high amino acid identity. They have similar roles in convergent extension during development, lymphatic development, MMC identity in the nervous system, retinal development, and aortic valve calcification (see Table 1). However, WNT5B exhibits unique, often opposing, effects on development and homeostasis in many tissue types including bone, adipose tissue, mammary gland, and myeloid cells. Non-canonical WNT5B functions through both WNT-PCP and WNT-Ca ${ }^{2+}$ signaling pathways, which are responsible for not only cell movement,

\section{REFERENCES}

Abad, V., Meyers, J. L., Weise, M., Gafni, R. I., Barnes, K. M., Nilsson, O., et al. (2002). The role of the resting zone in growth plate chondrogenesis. Endocrinology 143, 1851-1857. doi: 10.1210/endo.143.5.8776

Agalliu, D., Takada, S., Agalliu, I., McMahon, A. P., and Jessell, T. M. (2009). Motor neurons with axial muscle projections specified by Wnt4/5 signaling. Neuron 61, 708-720. doi: 10.1016/j.neuron.2008.12.026

Agostino, M., Pohl, S. O., and Dharmarajan, A. (2017). Structure-based prediction of Wnt binding affinities for Frizzled-type cysteine-rich domains. J. Biol. Chem. 292, 11218-11229. doi: 10.1074/jbc.m117.786269

Akoumianakis, I., Sanna, F., Margaritis, M., Badi, I., Akawi, N., Herdman, L., et al. (2019). Adipose tissue-derived WNT5A regulates vascular redox signaling in obesity via USP17/RAC1-mediated activation of NADPH oxidases. Sci. Transl. Med. 11:eaav5055. doi: 10.1126/scitranslmed.aav5055

Albanese, I., Yu, B., Al-Kindi, H., Barratt, B., Ott, L., Al-Refai, M., et al. (2017). Role of noncanonical Wnt signaling pathway in human aortic valve calcification. Arterioscler. Thromb. Vasc. Biol. 37, 543-552. doi: 10.1161/atvbaha.116.308394

Amjadi-Moheb, F., Hosseini, S. R., Kosari-Monfared, M., Ghadami, E., Nooreddini, H., and Akhavan-Niaki, H. (2018). A specific haplotype in potential miRNAs binding sites of secreted frizzled-related protein 1 (SFRP1) is associated with BMD variation in osteoporosis. Gene 677, 132-141. doi: 10.1016/j.gene.2018.07.061

Anderson, G., and Jenkinson, E. J. (2001). Lymphostromal interactions in thymic development and function. Nat. Rev. Immunol. 1, 31-40. doi: 10.1038/ 35095500

Andre, P., Song, H., Kim, W., Kispert, A., and Yang, Y. (2015). Wnt5a and Wnt11 regulate mammalian anterior-posterior axis elongation. Development 142, 1516-1527. doi: 10.1242/dev.119065

Aoki, K., and Taketo, M. M. (2007). Adenomatous polyposis coli (APC): a multifunctional tumor suppressor gene. J. Cell Sci. 120, 3327-3335. doi: 10.1242/jcs. 03485

Azbazdar, Y., Karabicici, M., Erdal, E., and Ozhan, G. (2021). Regulation of Wnt signaling pathways at the plasma membrane and their misregulation in cancer. Front. Cell Dev. Biol. 9:631623. doi: 10.3389/fcell.2021.631623

Baarsma, H. A., Skronska-Wasek, W., Mutze, K., Ciolek, F., Wagner, D. E., John-Schuster, G., et al. (2017). Noncanonical WNT-5A signaling impairs endogenous lung repair in COPD. J. Exp. Med. 214, 143-163. doi: 10.1084/ jem.20160675 but also cell proliferation, and cell differentiation. Disrupted WNT5B signaling leads to the progression of diseases such as osteoarthritis, osteoporosis, obesity, type 2 diabetes mellitus and chronic diseases associated with aging, as well as cancers. Understanding the mechanistic effects of WNT5B, which are not well known, could be translated to the development of potential therapies.

\section{AUTHOR CONTRIBUTIONS}

All authors listed have made a substantial, direct and intellectual contribution to the work, and approved it for publication.

\section{FUNDING}

Work in VB laboratory is supported by European Structural and Investment Funds, Operational Programme Research, Development and Education - "Preclinical Progression of New Organic Compounds with Targeted Biological Activity" (Preclinprogress) - CZ.02.1.01/0.0/0.0/16_025/0007381.

Bailey, P., Chang, D. K., Nones, K., Johns, A. L., Patch, A. M., Gingras, M. C., et al. (2016). Genomic analyses identify molecular subtypes of pancreatic cancer. Nature 531, 47-52.

Bakker, E. R., Das, A. M., Helvensteijn, W., Franken, P. F., Swagemakers, S., van der Valk, M. A., et al. (2013). Wnt5a promotes human colon cancer cell migration and invasion but does not augment intestinal tumorigenesis in Apc1638N mice. Carcinogenesis 34, 2629-2638. doi: 10.1093/carcin/bgt215

Balciunaite, G., Keller, M. P., Balciunaite, E., Piali, L., Zuklys, S., Mathieu, Y. D., et al. (2002). Wnt glycoproteins regulate the expression of FoxN1, the gene defective in nude mice. Nat. Immunol. 3, 1102-1108. doi: 10.1038/ni850

Banziger, C., Soldini, D., Schutt, C., Zipperlen, P., Hausmann, G., and Basler, K. (2006). Wntless, a conserved membrane protein dedicated to the secretion of Wnt proteins from signaling cells. Cell 125, 509-522. doi: 10.1016/j.cell.2006. 02.049

Bergstein, I., Eisenberg, L. M., Bhalerao, J., Jenkins, N. A., Copeland, N. G., Osborne, M. P., et al. (1997). Isolation of two novel WNT genes, WNT14 and WNT15, one of which (WNT15) is closely linked to WNT3 on human chromosome 17q21. Genomics 46, 450-458. doi: 10.1006/geno.1997. 5041

Bitler, B. G., Nicodemus, J. P., Li, H., Cai, Q., Wu, H., Hua, X., et al. (2011). Wnt5a suppresses epithelial ovarian cancer by promoting cellular senescence. Cancer Res. 71, 6184-6194. doi: 10.1158/0008-5472.can-11-1341

Blanton, S. H., Bertin, T., Serna, M. E., Stal, S., Mulliken, J. B., and Hecht, J. T. (2004). Association of chromosomal regions 3p21.2, 10p13, and 16p13.3 with nonsyndromic cleft lip and palate. Am. J. Med. Genet. A 125A, 23-27. doi: 10.1002/ajmg.a.20426

Bo, H., Gao, L., Chen, Y., Zhang, J., and Zhu, M. (2016). Upregulation of the expression of Wnt5a promotes the proliferation of pancreatic cancer cells in vitro and in a nude mouse model. Mol. Med. Rep. 13, 1163-1171. doi: 10.3892/mmr.2015.4642

Bradley, E. W., and Drissi, M. H. (2011). Wnt5b regulates mesenchymal cell aggregation and chondrocyte differentiation through the planar cell polarity pathway. J. Cell. Physiol. 226, 1683-1693. doi: 10.1002/jcp.22499

Brommage, R., Liu, J., Hansen, G. M., Kirkpatrick, L. L., Potter, D. G., Sands, A. T., et al. (2014). High-throughput screening of mouse gene knockouts identifies established and novel skeletal phenotypes. Bone Res. 2:14034.

Burn, S. F., Webb, A., Berry, R. L., Davies, J. A., Ferrer-Vaquer, A., Hadjantonakis, A. K., et al. (2011). Calcium/NFAT signalling promotes early nephrogenesis. Dev. Biol. 352, 288-298. doi: 10.1016/j.ydbio.2011.01.033 
Chakravadhanula, M., Hampton, C. N., Chodavadia, P., Ozols, V., Zhou, L., Catchpoole, D., et al. (2015). Wnt pathway in atypical teratoid rhabdoid tumors. Neuro. Oncol. 17, 526-535. doi: 10.1093/neuonc/nou229

Charoenpanich, A., Wall, M. E., Tucker, C. J., Andrews, D. M., Lalush, D. S., Dirschl, D. R., et al. (2014). Cyclic tensile strain enhances osteogenesis and angiogenesis in mesenchymal stem cells from osteoporotic donors. Tissue Eng. Part A 20, 67-78. doi: 10.1089/ten.tea.2013.0006

Chen, G., Wang, Q., Li, Z., Yang, Q., Liu, Y., Du, Z., et al. (2020). Circular RNA CDR1as promotes adipogenic and suppresses osteogenic differentiation of BMSCs in steroid-induced osteonecrosis of the femoral head. Bone 133:115258. doi: 10.1016/j.bone.2020.115258

Chen, Y., Chen, Z., Tang, Y., and Xiao, Q. (2021). The involvement of noncanonical Wnt signaling in cancers. Biomed. Pharmacother. 133:110946. doi: 10.1016/j. biopha.2020.110946

Cheng, R., Sun, B., Liu, Z., Zhao, X., Qi, L., Li, Y., et al. (2014). Wnt5a suppresses colon cancer by inhibiting cell proliferation and epithelial-mesenchymal transition. J. Cell Physiol. 229, 1908-1917. doi: 10.1002/jcp.24566

Choi, M. R., Jung, K. H., Park, J. H., Das, N. D., Chung, M. K., Choi, I. G., et al. (2011). Ethanol-induced small heat shock protein genes in the differentiation of mouse embryonic neural stem cells. Arch. Toxicol. 85, 293-304. doi: 10.1007/ s00204-010-0591-z

Choudhary, P., Dodsworth, B. T., Sidders, B., Gutteridge, A., Michaelides, C., Duckworth, J. K., et al. (2015). A FOXM1 dependent mesenchymal-epithelial transition in retinal pigment epithelium cells. PLoS One 10:e0130379. doi: 10. 1371/journal.pone.0130379

Church, D. M., Goodstadt, L., Hillier, L. W., Zody, M. C., Goldstein, S., She, X., et al. (2009). Lineage-specific biology revealed by a finished genome assembly of the mouse. PLoS Biol. 7:e1000112. doi: 10.1371/journal.pbio.1000112

Church, V., Nohno, T., Linker, C., Marcelle, C., and Francis-West, P. (2002). Wnt regulation of chondrocyte differentiation. J. Cell Sci. 115, 4809-4818. doi: $10.1242 /$ jcs. 00152

Clevers, H., and Nusse, R. (2012). Wnt/beta-catenin signaling and disease. Cell 149, 1192-1205.

Dahiya, S., Saini, V., Kumar, P., and Kumar, A. (2019). Insights into molecular interactions of human Wnt5b and Frizzled proteins for their role in teratogenicity. Bioinformation 15, 246-254. doi: 10.6026/973206300 15246

Daudet, N., Ripoll, C., Moles, J. P., and Rebillard, G. (2002). Expression of members of Wnt and Frizzled gene families in the postnatal rat cochlea. Brain. Res. Mol. Brain Res. 105, 98-107. doi: 10.1016/s0169-328x(02)00397-2

de Rezende, M. M., Ng-Blichfeldt, J. P., Justo, G. Z., Paredes-Gamero, E. J., and Gosens, R. (2020). Divergent effects of Wnt5b on IL-3- and GM-CSF-induced myeloid differentiation. Cell. Signal. 67:109507. doi: 10.1016/j.cellsig.2019. 109507

Dejmek, J., Safholm, A., Kamp Nielsen, C., Andersson, T., and Leandersson, K. (2006). Wnt-5a/Ca2+-induced NFAT activity is counteracted by Wnt-5a/YesCdc42-casein kinase 1alpha signaling in human mammary epithelial cells. Mol. Cell. Biol. 26, 6024-6036. doi: 10.1128/mcb.02354-05

Dhasmana, D., Veerapathiran, S., Azbazdar, Y., Nelanuthala, A. V. S., Teh, C., Ozhan, G., et al. (2021). Wnt3 is lipidated at conserved cysteine and serine residues in zebrafish neural tissue. Front. Cell Dev. Biol. 9:671218. doi: 10.3389/ fcell.2021.671218

Dijkgraaf, L. C., de Bont, L. G. M., Boering, G., and Liem, R. S. B. (1995). The structure, biochemistry, and metabolism of osteoarthritic cartilage: a review of the literature. J. Oral Maxillofac. Surg. 53, 1182-1192. doi: 10.1016/02782391(95)90632-0

Dong, J.-J., Ying, L., and Shi, K.-O. (2019). Expression of the Wnt ligands gene family and its relationship to prognosis in hepatocellular carcinoma. Cancer Cell Int. 19:34. doi: 10.1186/s12935-019-0743-z

Duesterdieck-Zellmer, K., Semevolos, S., Kinsley, M., and Riddick, T. (2015). Agerelated differential gene and protein expression in postnatal cartilage canal and osteochondral junction chondrocytes. Gene Expr. Patterns 17, 1-10. doi: 10.1016/j.gep.2014.11.002

Enomoto, M., Hayakawa, S., Itsukushima, S., Ren, D. Y., Matsuo, M., Tamada, K., et al. (2009). Autonomous regulation of osteosarcoma cell invasiveness by Wnt5a/Ror2 signaling. Oncogene 28, 3197-3208. doi: 10.1038/onc.2009.175

Estrada, K., Styrkarsdottir, U., Evangelou, E., Hsu, Y. H., Duncan, E. L., Ntzani, E. E., et al. (2012). Genome-wide meta-analysis identifies 56 bone mineral density loci and reveals 14 loci associated with risk of fracture. Nat. Genet. 44 , 491-501.

Fanto, M., Weber, U., Strutt, D. I., and Mlodzik, M. (2000). Nuclear signaling by Rac and Rho GTPases is required in the establishment of epithelial planar polarity in the Drosophila eye. Curr. Biol. 10, 979-988. doi: 10.1016/s09609822(00)00645-x

Fazzi, R., Pacini, S., Carnicelli, V., Trombi, L., Montali, M., Lazzarini, E., et al. (2011). Mesodermal progenitor cells (MPCs) differentiate into mesenchymal stromal cells (MSCs) by activation of Wnt5/calmodulin signalling pathway. PLoS One 6:e25600. doi: 10.1371/journal.pone.0025600

Galli, L. M., Barnes, T. L., Secrest, S. S., Kadowaki, T., and Burrus, L. W. (2007). Porcupine-mediated lipid-modification regulates the activity and distribution of Wnt proteins in the chick neural tube. Development 134, 3339-3348. doi: 10.1242/dev.02881

Gatica-Andrades, M., Vagenas, D., Kling, J., Nguyen, T. T. K., Benham, H., Thomas, R., et al. (2017). WNT ligands contribute to the immune response during septic shock and amplify endotoxemia-driven inflammation in mice. Blood Adv. 1, 1274-1286. doi: 10.1182/bloodadvances.2017006163

Gavin, B. J., and McMahon, A. P. (1992). Differential regulation of the Wnt gene family during pregnancy and lactation suggests a role in postnatal development of the mammary gland. Mol. Cell. Biol. 12, 2418-2423. doi: 10.1128/mcb.12.5. 2418

Gavin, B. J., McMahon, J. A., and McMahon, A. P. (1990). Expression of multiple novel Wnt-1/int-1-related genes during fetal and adult mouse development. Genes Dev. 4, 2319-2332. doi: 10.1101/gad.4.12b.2319

Gerdes, J. M., Liu, Y., Zaghloul, N. A., Leitch, C. C., Lawson, S. S., Kato, M., et al. (2007). Disruption of the basal body compromises proteasomal function and perturbs intracellular Wnt response. Nat. Genet. 39, 1350-1360.

Gu, Q., Tian, H., Zhang, K., Chen, D., Chen, D., Wang, X., et al. (2018). Wnt5a/FZD4 mediates the mechanical stretch-induced osteogenic differentiation of bone mesenchymal stem cells. Cell. Physiol. Biochem. 48, 215-226. doi: 10.1159/000491721

Guder, C., Philipp, I., Lengfeld, T., Watanabe, H., Hobmayer, B., and Holstein, T. W. (2006). The Wnt code: cnidarians signal the way. Oncogene 25, 74507460. doi: $10.1038 /$ sj.onc. 1210052

Gupta, K., and Schnell, E. (2019). Neuronal network remodeling and Wnt pathway dysregulation in the intra-hippocampal kainate mouse model of temporal lobe epilepsy. PLoS One 14:e0215789. doi: 10.1371/journal.pone.02 15789

Gutzman, J. H., Graeden, E., Brachmann, I., Yamazoe, S., Chen, J. K., and Sive, H. (2018). Basal constriction during midbrain-hindbrain boundary morphogenesis is mediated by Wnt5b and focal adhesion kinase. Biol. Open 7:bio034520. doi: 10.1242/bio.034520

Habas, R., Kato, Y., and He, X. (2001). Wnt/Frizzled activation of rho regulates vertebrate gastrulation and requires a novel formin homology protein Daam1. Cell 107, 843-854. doi: 10.1016/s0092-8674(01)00614-6

Harada, T., Yamamoto, H., Kishida, S., Kishida, M., Awada, C., Takao, T., et al. (2017). Wnt5b-associated exosomes promote cancer cell migration and proliferation. Cancer Sci. 108, 42-52. doi: 10.1111/cas.13109

Hart, M., Concordet, J. P., Lassot, I., Albert, I., del los Santos, R., Durand, H., et al. (1999). The F-box protein beta-TrCP associates with phosphorylated beta-catenin and regulates its activity in the cell. Curr. Biol. 9, 207-210. doi: 10.1016/s0960-9822(99)80091-8

He, F., Xiong, W., Yu, X., Espinoza-Lewis, R., Liu, C., Gu, S., et al. (2008). Wnt5a regulates directional cell migration and cell proliferation via Ror2-mediated noncanonical pathway in mammalian palate development. Development 135 , 3871-3879. doi: 10.1242/dev.025767

Heijink, I. H., de Bruin, H. G., Dennebos, R., Jonker, M. R., Noordhoek, J. A., Brandsma, C. A., et al. (2016). Cigarette smoke-induced epithelial expression of WNT-5B: implications for COPD. Eur. Respir. J. 48, 504-515. doi: 10.1183/ 13993003.01541-2015

Heilmann, A., Schinke, T., Bindl, R., Wehner, T., Rapp, A., Haffner-Luntzer, M., et al. (2013). The Wnt serpentine receptor Frizzled-9 regulates new bone formation in fracture healing. PLoS One 8:e84232. doi: 10.1371/journal.pone.0084232

Heller, R. S., Dichmann, D. S., Jensen, J., Miller, C., Wong, G., Madsen, O. D., et al. (2002). Expression patterns of Wnts, Frizzleds, sFRPs, and misexpression in transgenic mice suggesting a role for Wnts in pancreas 
and foregut pattern formation. Dev. Dyn. 225, 260-270. doi: 10.1002/dvdy. 10157

Hino, M., Kamo, M., Saito, D., Kyakumoto, S., Shibata, T., Mizuki, H., et al. (2016). Transforming growth factor-betal induces invasion ability of HSC-4 human oral squamous cell carcinoma cells through the Slug/Wnt5b/MMP-10 signalling axis. J. Biochem. 159, 631-640. doi: 10.1093/jb/ mvw007

Hopwood, B., Tsykin, A., Findlay, D. M., and Fazzalari, N. L. (2007). Microarray gene expression profiling of osteoarthritic bone suggests altered bone remodelling, WNT and transforming growth factor-beta/bone morphogenic protein signalling. Arthritis Res. Ther. 9:R100.

Houschyar, K. S., Tapking, C., Borrelli, M. R., Popp, D., Duscher, D., Maan, Z. N., et al. (2018). Wnt pathway in bone repair and regeneration - what do we know so far. Front. Cell Dev. Biol. 6:170. doi: 10.3389/fcell.2018.00170

Huang, C. L., Liu, D., Nakano, J., Ishikawa, S., Kontani, K., Yokomise, H., et al. (2005). Wnt5a expression is associated with the tumor proliferation and the stromal vascular endothelial growth factor-an expression in non-small-cell lung cancer. J. Clin. Oncol. 23, 8765-8773. doi: 10.1200/jco.2005.02.2871

Huang, J., Chen, C., Liang, C., Luo, P., Xia, G., Zhang, L., et al. (2020). Dysregulation of the Wnt signaling pathway and synovial stem cell dysfunction in osteoarthritis development. Stem Cells Dev. 29, 401-413. doi: 10.1089/scd. 2019.0260

Huang, T. C., Lee, P. T., Wu, M. H., Huang, C. C., Ko, C. Y., Lee, Y. C., et al. (2017), Distinct roles and differential expression levels of Wnt5a mRNA isoforms in colorectal cancer cells. PLoS One 12:e0181034. doi: 10.1371/journal.pone. 0181034

Hung, I. C., Chen, T. M., Lin, J. P., Tai, Y. L., Shen, T. L., and Lee, S. J. (2020). Wnt5b integrates Fakla to mediate gastrulation cell movements via Racl and Cdc42. Open Biol. 10:190273. doi: 10.1098/rsob.190273

Hunziker, E. B. (1994). Mechanism of longitudinal bone growth and its regulation by growth plate chondrocytes. Microsc. Res. Tech. 28, 505-519. doi: 10.1002/ jemt.1070280606

Hurson, C. J., Butler, J. S., Keating, D. T., Murray, D. W., Sadlier, D. M., O’Byrne, J. M., et al. (2007). Gene expression analysis in human osteoblasts exposed to dexamethasone identifies altered developmental pathways as putative drivers of osteoporosis. BMC Musculoskelet. Disord. 8:12. doi: 10.1186/1471-2474-8-12

Imel, E. A., DiMeglio, L. A., and Burr, D. B. (2014). "Chapter 16 - metabolic bone diseases," in Basic and Applied Bone Biology, eds D. B. Burr and M. R. Allen (San Diego, CA: Academic Press), 317-344.

Iozzo, R. V., Eichstetter, I., and Danielson, K. G. (1995). Aberrant expression of the growth factor Wnt-5A in human malignancy. Cancer Res. 55, 3495-3499.

Janovska, P., Poppova, L., Plevova, K., Plesingerova, H., Behal, M., Kaucka, M., et al. (2016). Autocrine signaling by Wnt-5a deregulates chemotaxis of leukemic cells and predicts clinical outcome in chronic lymphocytic leukemia. Clin. Cancer Res. 22, 459-469. doi: 10.1158/1078-0432.ccr-15-0154

Ji, H., Goode, R. J., Vaillant, F., Mathivanan, S., Kapp, E. A., Mathias, R. A., et al. (2011). Proteomic profiling of secretome and adherent plasma membranes from distinct mammary epithelial cell subpopulations. Proteomics 11, 4029-4039. doi: $10.1002 /$ pmic. 201100102

Jia, H. L., and Zhou, D. S. (2018). Downregulation of microRNA-367 promotes osteoblasts growth and proliferation of mice during fracture by activating the PANX3-mediated Wnt/beta-catenin pathway. J. Cell. Biochem. doi: 10.1002/jcb. 28108 [Epub ahead of print].

Jiang, S., Zhang, M., Zhang, Y., Zhou, W., Zhu, T., Ruan, Q., et al. (2019). WNT5B governs the phenotype of basal-like breast cancer by activating WNT signaling. Cell Commun. Signal. 17:109.

Kanazawa, A., Tsukada, S., Kamiyama, M., Yanagimoto, T., Nakajima, M., and Maeda, S. (2005). Wnt5b partially inhibits canonical Wnt/beta-catenin signaling pathway and promotes adipogenesis in 3T3-L1 preadipocytes. Biochem. Biophys. Res. Commun. 330, 505-510. doi: 10.1016/j.bbrc.2005.03.007

Kanazawa, A., Tsukada, S., Sekine, A., Tsunoda, T., Takahashi, A., Kashiwagi, A., et al. (2004). Association of the gene encoding wingless-type mammary tumor virus integration-site family member $5 \mathrm{~B}$ (WNT5B) with type 2 diabetes. Am. J. Hum. Genet. 75, 832-843. doi: 10.1086/425340

Karp, S. J., Schipani, E., St-Jacques, B., Hunzelman, J., Kronenberg, H., and McMahon, A. P. (2000). Indian hedgehog coordinates endochondral bone growth and morphogenesis via parathyroid hormone related-proteindependent and -independent pathways. Development 127, 543-548.
Katanaev, V., and Buestorf, S. (2009). Frizzled Proteins are bona fide G proteincoupled receptors. Nat. Preced. doi: 10.1038/npre.2009.2765.1

Kato, S., Hayakawa, Y., Sakurai, H., Saiki, I., and Yokoyama, S. (2014). Mesenchymal-transitioned cancer cells instigate the invasion of epithelial cancer cells through secretion of WNT3 and WNT5B. Cancer Sci. 105, 281-289. doi: $10.1111 /$ cas. 12336

Katoh, M., and Katoh, M. (2005). Comparative genomics on Wnt5a and Wnt5b genes. Int. J. Mol. Med. 15, 749-753.

Kemp, J. P., Medina-Gomez, C., Estrada, K., St Pourcain, B., Heppe, D. H., Warrington, N. M., et al. (2014). Phenotypic dissection of bone mineral density reveals skeletal site specificity and facilitates the identification of novel loci in the genetic regulation of bone mass attainment. PLoS Genet. 10:e1004423. doi: 10.1371/journal.pgen.1004423

Kessenbrock, K., Smith, P., Steenbeek, S. C., Pervolarakis, N., Kumar, R. Minami, Y., et al. (2017). Diverse regulation of mammary epithelial growth and branching morphogenesis through noncanonical Wnt signaling. Proc. Natl. Acad. Sci. U. S. A. 114, 3121-3126. doi: 10.1073/pnas.1701464 114

Khan, K., Yu, B., Kiwan, C., Shalal, Y., Filimon, S., Cipro, M., et al. (2020). The role of Wnt/beta-catenin pathway mediators in aortic valve stenosis. Front. Cell Dev. Biol. 8:862. doi: 10.3389/fcell.2020.00862

Kilander, M. B., Dahlstrom, J., and Schulte, G. (2014). Assessment of Frizzled 6 membrane mobility by FRAP supports $\mathrm{G}$ protein coupling and reveals WNTFrizzled selectivity. Cell. Signal. 26, 1943-1949. doi: 10.1016/j.cellsig.2014. 05.012

Kitagawa, M., Hatakeyama, S., Shirane, M., Matsumoto, M., Ishida, N., Hattori, K., et al. (1999). An F-box protein, FWD1, mediates ubiquitin-dependent proteolysis of beta-catenin. $E M B O J .18,2401-2410$. doi: 10.1093/emboj/18. 9.2401

Kuhl, M., Sheldahl, L. C., Malbon, C. C., and Moon, R. T. (2000). $\mathrm{Ca}(2+) /$ calmodulin-dependent protein kinase II is stimulated by Wnt and Frizzled homologs and promotes ventral cell fates in Xenopus. J. Biol. Chem. 275, 12701-12711. doi: 10.1074/jbc.275.17.12701

Kumarasinghe, D. D., Sullivan, T., Kuliwaba, J. S., Fazzalari, N. L., and Atkins, G. J. (2012). Evidence for the dysregulated expression of TWIST1, TGFbetal and SMAD3 in differentiating osteoblasts from primary hip osteoarthritis patients. Osteoarthritis Cartilage 20, 1357-1366. doi: 10.1016/j.joca.2012.07.005

Lecarpentier, Y., Schussler, O., Hébert, J.-L., and Vallée, A. (2019). Multiple targets of the canonical WNT/ $\beta$-catenin signaling in cancers. Front. Oncol. 9:1248. doi: $10.3389 /$ fonc. 2019.01248

Li, Q., and Chen, H. (2012). Silencing of Wnt5a during colon cancer metastasis involves histone modifications. Epigenetics 7, 551-558. doi: 10.4161/epi. 20050

Lickert, H., Kispert, A., Kutsch, S., and Kemler, R. (2001). Expression patterns of Wnt genes in mouse gut development. Mech. Dev. 105, 181-184. doi: 10.1016/ s0925-4773(01)00390-2

Lin, S., Baye, L. M., Westfall, T. A., and Slusarski, D. C. (2010). Wnt5b-Ryk pathway provides directional signals to regulate gastrulation movement. J. Cell. Biol. 190, 263-278. doi: 10.1083/jcb.200912128

Liu, H., Mohamed, O., Dufort, D., and Wallace, V. A. (2003). Characterization of Wnt signaling components and activation of the Wnt canonical pathway in the murine retina. Dev. Dyn. 227, 323-334. doi: 10.1002/dvdy.10315

Liu, S., Liu, Y. P., Huang, Z. J., Zhang, Y. K., Song, A. A., Ma, P. C., et al. (2015). Wnt/Ryk signaling contributes to neuropathic pain by regulating sensory neuron excitability and spinal synaptic plasticity in rats. Pain 156, 2572-2584. doi: $10.1097 /$ j.pain. 0000000000000366

Liu, X., Chen, W., Zhou, Y., Tang, K., and Zhang, J. (2015). Mechanical tension promotes the osteogenic differentiation of rat tendon-derived stem cells through the Wnt5a/Wnt5b/JNK signaling pathway. Cell. Physiol. Biochem. 36, 517-530. doi: $10.1159 / 000430117$

Louwette, S., Labarque, V., Wittevrongel, C., Thys, C., Metz, J., Gijsbers, R., et al. (2012). Regulator of G-protein signaling 18 controls megakaryopoiesis and the cilia-mediated vertebrate mechanosensory system. FASEB J. 26, 2125-2136. doi: $10.1096 /$ fj.11-198739

Lu, B. J., Wang, Y. Q., Wei, X. J., Rong, L. Q., Wei, D., Yan, C. M. et al. (2012). Expression of WNT-5a and ROR2 correlates with disease severity in osteosarcoma. Mol. Med. Rep. 5, 1033-1036. doi: 10.3892/mmr.20 12.772 
Lu, D., Zhao, Y., Tawatao, R., Cottam, H. B., Sen, M., Leoni, L. M., et al. (2004). Activation of the Wnt signaling pathway in chronic lymphocytic leukemia. Proc. Natl. Acad. Sci. U. S. A. 101, 3118-3123. doi: 10.1073/pnas.0308648100

Lutze, G., Haarmann, A., Demanou Toukam, J. A., Buttler, K., Wilting, J., and Becker, J. (2019). Non-canonical WNT-signaling controls differentiation of lymphatics and extension lymphangiogenesis via RAC and JNK signaling. Sci. Rep. 9:4739.

Maeda, K., Kobayashi, Y., Udagawa, N., Uehara, S., Ishihara, A., Mizoguchi, T., et al. (2012). Wnt5a-Ror2 signaling between osteoblast-lineage cells and osteoclast precursors enhances osteoclastogenesis. Nat. Med. 18, 405-412. doi: $10.1038 / \mathrm{nm} .2653$

Marsell, R., and Einhorn, T. A. (2011). The biology of fracture healing. Injury 42, 551-555.

Martin, V., Valencia, A., Agirre, X., Cervera, J., San Jose-Eneriz, E., Vilas-Zornoza, A., et al. (2010). Epigenetic regulation of the non-canonical Wnt pathway in acute myeloid leukemia. Cancer Sci. 101, 425-432. doi: 10.1111/j.1349-7006. 2009.01413.x

Martineau, X., Abed, E., Martel-Pelletier, J., Pelletier, J. P., and Lajeunesse, D. (2017). Alteration of Wnt5a expression and of the non-canonical Wnt/PCP and Wnt/PKC-Ca2+ pathways in human osteoarthritis osteoblasts. PLoS One 12:e0180711. doi: 10.1371/journal.pone.0180711

Matsukawa, T., Morita, K., Omizu, S., Kato, S., and Koriyama, Y. (2018). Mechanisms of RhoA inactivation and CDC42 and Racl activation during zebrafish optic nerve regeneration. Neurochem. Int. 112, 71-80. doi: 10.1016/j. neuint.2017.11.004

Mattes, B., Dang, Y., Greicius, G., Kaufmann, L. T., Prunsche, B., Rosenbauer, J., et al. (2018). Wnt/PCP controls spreading of Wnt/beta-catenin signals by cytonemes in vertebrates. Elife 7:e36953.

Mazzotta, S., Neves, C., Bonner, R. J., Bernardo, A. S., Docherty, K., and Hoppler, S. (2016). Distinctive roles of canonical and noncanonical Wnt signaling in human embryonic cardiomyocyte development. Stem Cell Rep. 7, 764-776. doi: 10.1016/j.stemcr.2016.08.008

Memarian, A., Hojjat-Farsangi, M., Asgarian-Omran, H., Younesi, V., JeddiTehrani, M., Sharifian, R. A., et al. (2009). Variation in WNT genes expression in different subtypes of chronic lymphocytic leukemia. Leuk. Lymphoma 50, 2061-2070. doi: 10.3109/10428190903331082

Miller, J. R. (2002). The Wnts. Genome Biol. 3:REVIEWS3001.

Minegishi, K., Hashimoto, M., Ajima, R., Takaoka, K., Shinohara, K., Ikawa, Y., et al. (2017). A Wnt5 activity asymmetry and intercellular signaling via PCP proteins polarize node cells for left-right symmetry breaking. Dev. Cell 40, 439-452.e4.

Mitchell, J. A., Chesi, A., Elci, O., McCormack, S. E., Roy, S. M., Kalkwarf, H. J., et al. (2016). Physical activity benefits the skeleton of children genetically predisposed to lower bone density in adulthood. J. Bone Miner. Res. 31, 1504-1512. doi: $10.1002 /$ jbmr.2872

Miyazaki, A., Sugimoto, A., Yoshizaki, K., Kawarabayashi, K., Iwata, K., Kurogoushi, R., et al. (2019). Coordination of WNT signaling and ciliogenesis during odontogenesis by piezo type mechanosensitive ion channel component 1. Sci. Rep. 9:14762.

Morioka, K., Tanikawa, C., Ochi, K., Daigo, Y., Katagiri, T., Kawano, H., et al. (2009). Orphan receptor tyrosine kinase ROR2 as a potential therapeutic target for osteosarcoma. Cancer Sci. 100, 1227-1233. doi: 10.1111/j.1349-7006.2009. 01165.x

Nicenboim, J., Malkinson, G., Lupo, T., Asaf, L., Sela, Y., Mayseless, O., et al. (2015). Lymphatic vessels arise from specialized angioblasts within a venous niche. Nature 522, 56-61. doi: 10.1038/nature 14425

Niehrs, C. (2012). The complex world of WNT receptor signalling. Nat. Rev. Mol. Cell. Biol. 13, 767-779. doi: 10.1038/nrm3470

Nusse, R., and Varmus, H. E. (1982). Many tumors induced by the mouse mammary tumor virus contain a provirus integrated in the same region of the host genome. Cell 31, 99-109. doi: 10.1016/0092-8674(82)90409-3

Okamoto, M., Udagawa, N., Uehara, S., Maeda, K., Yamashita, T., Nakamichi, Y., et al. (2014). Noncanonical Wnt5a enhances Wnt/beta-catenin signaling during osteoblastogenesis. Sci. Rep. 4:4493.

Paez, D., Gerger, A., Zhang, W., Yang, D., Labonte, M. J., Benhanim, L., et al. (2014). Association of common gene variants in the $\mathrm{WNT} /$ beta-catenin pathway with colon cancer recurrence. Pharmacogenomics J. 14, 142-150. doi: 10.1038/tpj. 2013.20
Park, H. W., Kim, Y. C., Yu, B., Moroishi, T., Mo, J. S., Plouffe, S. W., et al. (2015). Alternative Wnt signaling activates YAP/TAZ. Cell 162, 780-794. doi: 10.1016/j.cell.2015.07.013

Peng, C., Zhang, X., Yu, H., Wu, D., and Zheng, J. (2011). Wnt5a as a predictor in poor clinical outcome of patients and a mediator in chemoresistance of ovarian cancer. Int. J. Gynecol. Cancer 21, 280-288. doi: 10.1097/igc.0b013e31820 aaadb

Petrini, M., Pacini, S., Trombi, L., Fazzi, R., Montali, M., Ikehara, S., et al. (2009). Identification and purification of mesodermal progenitor cells from human adult bone marrow. Stem Cells Dev. 18, 857-866. doi: 10.1089/scd.2008. 0291

Qi, H., Sun, B., Zhao, X., Du, J., Gu, Q., Liu, Y., et al. (2014). Wnt5a promotes vasculogenic mimicry and epithelial-mesenchymal transition via protein kinase Calpha in epithelial ovarian cancer. Oncol. Rep. 32, 771-779. doi: 10.3892/or. 2014.3229

Raghavan, S., Mehta, P., Xie, Y., Lei, Y. L., and Mehta, G. (2019). Ovarian cancer stem cells and macrophages reciprocally interact through the WNT pathway to promote pro-tumoral and malignant phenotypes in $3 \mathrm{D}$ engineered microenvironments. J. Immunother. Cancer 7:190.

Ram Makena, M., Gatla, H., Verlekar, D., Sukhavasi, S., Pandey, M. K., and Pramanik, K. C. (2019). Wnt/beta-catenin signaling: the culprit in pancreatic carcinogenesis and therapeutic resistance. Int. J. Mol. Sci. 20:4242. doi: 10.3390/ ijms20174242

Rauner, M., Sipos, W., and Pietschmann, P. (2008). Age-dependent Wnt gene expression in bone and during the course of osteoblast differentiation. Age (Dordr) 30, 273-282. doi: 10.1007/s11357-008-9069-9

Ren, J., Han, P., Ma, X., Farah, E. N., Bloomekatz, J., Zeng, X. I., et al. (2019). Canonical Wnt5b signaling directs outlying Nkx2.5+ mesoderm into pacemaker cardiomyocytes. Dev. Cell 50:e725.

Rijsewijk, F., Schuermann, M., Wagenaar, E., Parren, P., Weigel, D., and Nusse, R. (1987). The drosophila homolog of the mouse mammary oncogene int1 is identical to the segment polarity gene wingless. Cell 50, 649-657. doi: 10.1016/0092-8674(87)90038-9

Rios-Esteves, J., Haugen, B., and Resh, M. D. (2014). Identification of key residues and regions important for porcupine-mediated Wnt acylation. J. Biol. Chem. 289, 17009-17019. doi: 10.1074/jbc.m114.561209

Robling, A. G., and Turner, C. H. (2009). Mechanical signaling for bone modeling and remodeling. Crit. Rev. Eukaryot. Gene Expr. 19, 319-338. doi: 10.1615/ critreveukargeneexpr.v19.i4.50

Rochard, L., Monica, S. D., Ling, I. T., Kong, Y., Roberson, S., Harland, R., et al. (2016). Roles of Wnt pathway genes wls, wnt9a, wnt5b, frzb and gpc4 in regulating convergent-extension during zebrafish palate morphogenesis. Development 143, 2541-2547. doi: 10.1242/dev.137000

Routledge, D., and Scholpp, S. (2019). Mechanisms of intercellular Wnt transport. Development 146:dev176073. doi: 10.1242/dev.176073

Saitoh, T., and Katoh, M. (2001). Molecular cloning and characterization of human WNT5B on chromosome 12p13.3 region. Int. J. Oncol. 19, 347-351.

Salpea, K. D., Gable, D. R., Cooper, J. A., Stephens, J. W., Hurel, S. J., Ireland, H. A., et al. (2009). The effect of WNT5B IVS3C $>$ G on the susceptibility to type 2 diabetes in UK Caucasian subjects. Nutr. Metab. Cardiovasc. Dis. 19, 140-145. doi: 10.1016/j.numecd.2008.02.009

Samanta, S., Guru, S., Elaimy, A. L., Amante, J. J., Ou, J., Yu, J., et al. (2018). IMP3 stabilization of WNT5B mRNA facilitates TAZ activation in breast cancer. Cell Rep. 23, 2559-2567. doi: 10.1016/j.celrep.2018.04.113

Santiago, F., Oguma, J., Brown, A. M., and Laurence, J. (2012). Noncanonical Wnt signaling promotes osteoclast differentiation and is facilitated by the human immunodeficiency virus protease inhibitor ritonavir. Biochem. Biophys. Res. Commun. 417, 223-230. doi: 10.1016/j.bbrc.2011.11.089

Sarin, S., Zuniga-Sanchez, E., Kurmangaliyev, Y. Z., Cousins, H., Patel, M., Hernandez, J., et al. (2018). Role for Wnt signaling in retinal neuropil development: analysis via RNA-seq and in vivo somatic CRISPR mutagenesis. Neuron 98:e108.

Schaffer, A. E., Taylor, B. L., Benthuysen, J. R., Liu, J., Thorel, F., Yuan, W., et al. (2013). Nkx6.1 controls a gene regulatory network required for establishing and maintaining pancreatic Beta cell identity. PLoS Genet. 9:e1003274. doi: 10.1371/journal.pgen.1003274

Schiffman, J. D., Hodgson, J. G., VandenBerg, S. R., Flaherty, P., Polley, M. Y., $\mathrm{Yu}, \mathrm{M}$., et al. (2010). Oncogenic BRAF mutation with CDKN2A inactivation 
is characteristic of a subset of pediatric malignant astrocytomas. Cancer Res. 70, 512-519. doi: 10.1158/0008-5472.can-09- 1851

Sharma, R. P., and Chopra, V. L. (1976). Effect of the wingless (wg1) mutation on wing and haltere development in Drosophila melanogaster. Dev. Biol. 48, 461-465. doi: 10.1016/0012-1606(76)90108-1

Shi, F. L., and Ren, L. X. (2020). Up-regulated miR-374a-3p relieves lipopolysaccharides induced injury in CHON-001 cells via regulating Winglesstype MMTV integration site family member 5B. Mol. Cell. Probes 51:101541. doi: 10.1016/j.mcp.2020.101541

Sisson, B. E., Dale, R. M., Mui, S. R., Topczewska, J. M., and Topczewski, J. (2015). A role of glypican 4 and wnt5b in chondrocyte stacking underlying craniofacial cartilage morphogenesis. Mech. Dev. 138 Pt 3, 279-290. doi: 10.1016/j.mod. 2015.10.001

Slusarski, D. C., Yang-Snyder, J., Busa, W. B., and Moon, R. T. (1997). Modulation of embryonic intracellular Ca2+ signaling by Wnt-5A. Dev. Biol. 182, 114-120. doi: 10.1006/dbio.1996.8463

Smith, A. R., Smith, R. G., Pishva, E., Hannon, E., Roubroeks, J. A. Y., Burrage, J., et al. (2019). Parallel profiling of DNA methylation and hydroxymethylation highlights neuropathology-associated epigenetic variation in Alzheimer's disease. Clin. Epigenetics 11:52.

Smolich, B. D., McMahon, J. A., McMahon, A. P., and Papkoff, J. (1993). Wnt family proteins are secreted and associated with the cell surface. Mol. Biol. Cell 4, 1267-1275. doi: 10.1091/mbc.4.12.1267

Spanjer, A. I., Baarsma, H. A., Oostenbrink, L. M., Jansen, S. R., Kuipers, C. C., Lindner, M., et al. (2016). TGF-beta-induced profibrotic signaling is regulated in part by the WNT receptor Frizzled-8. FASEB J. 30, 1823-1835. doi: 10.1096/ fj. 201500129

Stamos, J. L., and Weis, W. I. (2013). The beta-catenin destruction complex. Cold Spring Harb. Perspect. Biol. 5:a007898.

Steinhart, Z., and Angers, S. (2018). Wnt signaling in development and tissue homeostasis. Development 145:dev146589. doi: 10.1242/dev.146589

Stewart, D. J., Chang, D. W., Ye, Y., Spitz, M., Lu, C., Shu, X., et al. (2014). Wnt signaling pathway pharmacogenetics in non-small cell lung cancer. Pharmacogenomics J. 14, 509-522. doi: 10.1038/tpj.2014.21

Strutt, D. I., Weber, U., and Mlodzik, M. (1997). The role of RhoA in tissue polarity and Frizzled signalling. Nature 387, 292-295. doi: 10.1038/387292a0

Suomalainen, M., and Thesleff, I. (2010). Patterns of Wnt pathway activity in the mouse incisor indicate absence of Wnt/beta-catenin signaling in the epithelial stem cells. Dev. Dyn. 239, 364-372.

Takada, R., Satomi, Y., Kurata, T., Ueno, N., Norioka, S., Kondoh, H., et al. (2006). Monounsaturated fatty acid modification of Wnt protein: its role in Wnt secretion. Dev. Cell 11, 791-801. doi: 10.1016/j.devcel.2006.10.003

Takeshita, A., Iwai, S., Morita, Y., Niki-Yonekawa, A., Hamada, M., and Yura, Y. (2014). Wnt5b promotes the cell motility essential for metastasis of oral squamous cell carcinoma through active Cdc42 and RhoA. Int. J. Oncol. 44, 59-68. doi: 10.3892/ijo.2013.2172

Tang, Q., Chen, C., Zhang, Y., Dai, M., Jiang, Y., Wang, H., et al. (2018). Wnt5a regulates the cell proliferation and adipogenesis via MAPK-independent pathway in early stage of obesity. Cell Biol. Int. 42, 63-74. doi: 10.1002/cbin. 10862

Tao, J., Shi, L., Huang, L., Shi, H., Chen, H., Wang, Y., et al. (2017). EZH2 is involved in silencing of WNT5A during epithelial-mesenchymal transition of colon cancer cell line. J. Cancer Res. Clin. Oncol. 143, 2211-2219. doi: 10.1007/ s00432-017-2479-2

Tao, S. C., Yuan, T., Zhang, Y. L., Yin, W. J., Guo, S. C., and Zhang, C. Q. (2017). Exosomes derived from miR-140-5p-overexpressing human synovial mesenchymal stem cells enhance cartilage tissue regeneration and prevent osteoarthritis of the knee in a rat model. Theranostics 7, 180-195. doi: 10.7150/ thno. 17133

Taylor, B. L., Liu, F. F., and Sander, M. (2013). Nkx6.1 is essential for maintaining the functional state of pancreatic beta cells. Cell Rep. 4, 1262-1275. doi: 10 . 1016/j.celrep.2013.08.010

Vaidya, H., Rumph, C., and Katula, K. S. (2016). Inactivation of the WNT5A alternative promoter $\mathrm{B}$ is associated with DNA methylation and histone modification in osteosarcoma cell lines U2OS and SaOS-2. PLoS One 11:e0151392. doi: 10.1371/journal.pone.0151392 van Amerongen, R., and Nusse, R. (2009). Towards an integrated view of Wnt signaling in development. Development 136, 3205-3214. doi: 10.1242/dev. 033910

van Dijk, E. M., Menzen, M. H., Spanjer, A. I., Middag, L. D., Brandsma, C. A., and Gosens, R. (2016). Noncanonical WNT-5B signaling induces inflammatory responses in human lung fibroblasts. Am. J. Physiol. Lung Cell. Mol. Physiol. 310, L1166-L1176.

van Tienen, F. H., Laeremans, H., van der Kallen, C. J., and Smeets, H. J. (2009). Wnt5b stimulates adipogenesis by activating PPARgamma, and inhibiting the beta-catenin dependent Wnt signaling pathway together with Wnt5a. Biochem. Biophys. Res. Commun. 387, 207-211. doi: 10.1016/j.bbrc.2009.07.004

Vethe, H., Ghila, L., Berle, M., Hoareau, L., Haaland, O. A., Scholz, H., et al. (2019). The effect of Wnt pathway modulators on human iPSC-derived pancreatic beta cell maturation. Front. Endocrinol. (Lausanne) 10:293. doi: 10.3389/fendo.2019. 00293

Wang, Q., Symes, A. J., Kane, C. A., Freeman, A., Nariculam, J., Munson, P., et al. (2010). A novel role for Wnt/Ca2+ signaling in actin cytoskeleton remodeling and cell motility in prostate cancer. PLoS One 5:e10456. doi: 10.1371/journal. pone.0010456

Wang, S. H., Chang, J. S., Hsiao, J. R., Yen, Y. C., Jiang, S. S., Liu, S. H., et al. (2017). Tumour cell-derived WNT5B modulates in vitro lymphangiogenesis via induction of partial endothelial-mesenchymal transition of lymphatic endothelial cells. Oncogene 36, 1503-1515. doi: 10.1038/onc.20 16.317

Wang, X., Zhao, X., Yi, Z., Ma, B., Wang, H., Pu, Y., et al. (2018). WNT5A promotes migration and invasion of human osteosarcoma cells via SRC/ERK/MMP-14 pathway. Cell Biol. Int. 42, 598-607. doi: 10.1002/cbin.10936

Wei, W., Sun, H. H., Li, N., Li, H. Y., Li, X., Li, Q., et al. (2014). WNT5A modulates cell cycle progression and contributes to the chemoresistance in pancreatic cancer cells. Hepatobiliary Pancreat. Dis. Int. 13, 529-538. doi: 10.1016/s14993872(14)60277-0

Winter, C. G., Wang, B., Ballew, A., Royou, A., Karess, R., Axelrod, J. D., et al. (2001). Drosophila Rho-associated kinase (Drok) links Frizzled-mediated planar cell polarity signaling to the actin cytoskeleton. Cell 105, 81-91. doi: 10.1016/s0092-8674(01)00298-7

Witte, F., Dokas, J., Neuendorf, F., Mundlos, S., and Stricker, S. (2009). Comprehensive expression analysis of all Wnt genes and their major secreted antagonists during mouse limb development and cartilage differentiation. Gene Expr. Patterns 9, 215-223. doi: 10.1016/j.gep.2008.12.009

Wong, G. T., Gavin, B. J., and McMahon, A. P. (1994). Differential transformation of mammary epithelial cells by Wnt genes. Mol. Cell. Biol. 14, 6278-6286. doi: $10.1128 / \mathrm{mcb} .14 .9 .6278$

Wu, B. T., Wen, S. H., Hwang, S. P., Huang, C. J., and Kuan, Y. S. (2015). Control of Wnt5b secretion by Wntless modulates chondrogenic cell proliferation through fine-tuning fgf3 expression. J. Cell. Sci. 128, 2328-2339. doi: 10.1242/jcs. 167403

Wu, M., Li, Z., Liang, L., Ma, P., Cui, D., Chen, P., et al. (2020). Wnt signaling contributes to withdrawal symptoms from opioid receptor activation induced by morphine exposure or chronic inflammation. Pain 161, 532-544. doi: 10. $1097 /$ j.pain.0000000000001738

Wu, X., van Dijk, E. M., Ng-Blichfeldt, J. P., Bos, I. S. T., Ciminieri, C., Konigshoff, M., et al. (2019). Mesenchymal WNT-5A/5B signaling represses lung alveolar epithelial progenitors. Cells 8:1147. doi: 10.3390/cells8101147

Xiao, Q., Chen, Z., Jin, X., Mao, R., and Chen, Z. (2017). The many postures of noncanonical Wnt signaling in development and diseases. Biomed. Pharmacother. 93, 359-369. doi: 10.1016/j.biopha.2017.06.061

Xu, A., Yang, H., Gao, K., Zhan, Z., Song, Z., Huang, T., et al. (2020). Expression profiles and prognostic significance of WNT family members in glioma via bioinformatic analysis. Biosci. Rep. 40:BSR20194255.

Xuan, F., Yano, F., Mori, D., Chijimatsu, R., Maenohara, Y., Nakamoto, H., et al. (2019). Wnt/beta-catenin signaling contributes to articular cartilage homeostasis through lubricin induction in the superficial zone. Arthritis Res. Ther. 21:247.

Yamaguchi, T. P., Bradley, A., McMahon, A. P., and Jones, S. (1999). A Wnt5a pathway underlies outgrowth of multiple structures in the vertebrate embryo. Development 126, 1211-1223. 
Yang, L., Perez, A. A., Fujie, S., Warden, C., Li, J., Wang, Y., et al. (2014). Wnt modulates MCL1 to control cell survival in triple negative breast cancer. BMC Cancer 14:124. doi: 10.1186/1471-2407-14-124

Yang, Y., Topol, L., Lee, H., and Wu, J. (2003). Wnt5a and Wnt5b exhibit distinct activities in coordinating chondrocyte proliferation and differentiation. Development 130, 1003-1015. doi: 10.1242/dev.00324

Yao, C. J., Lv, Y., Zhang, C. J., Jin, J. X., Xu, L. H., Jiang, J., et al. (2018). MicroRNA185 inhibits the growth and proliferation of osteoblasts in fracture healing by targeting PTH gene through down-regulating Wnt/beta -catenin axis: in an animal experiment. Biochem. Biophys. Res. Commun. 501, 55-63. doi: 10.1016/ j.bbrc.2018.04.138

Ye, Z., Zhang, C., Tu, T., Sun, M., Liu, D., Lu, D., et al. (2013). Wnt5a uses CD146 as a receptor to regulate cell motility and convergent extension. Nat. Commun. 4:2803.

Yi, H., Nakamura, R. E., Mohamed, O., Dufort, D., and Hackam, A. S. (2007). Characterization of Wnt signaling during photoreceptor degeneration. Invest. Ophthalmol. Vis. Sci. 48, 5733-5741. doi: 10.1167/iovs.07-0097

Yin, P., Bai, Y., Wang, Z., Sun, Y., Gao, J., Na, L., et al. (2020). Non-canonical Fzd7 signaling contributes to breast cancer mesenchymal-like stemness involving Col6a1. Cell Commun. Signal. 18:143.

Yuzugullu, H., Benhaj, K., Ozturk, N., Senturk, S., Celik, E., Toylu, A., et al. (2009). Canonical Wnt signaling is antagonized by noncanonical Wnt5a in hepatocellular carcinoma cells. Mol. Cancer 8:90. doi: 10.1186/1476-45 98-8-90

Zeng, R., Huang, J., Zhong, M. Z., Li, L., Yang, G., Liu, L., et al. (2016). Multiple roles of WNT5A in breast cancer. Med. Sci. Monit. 22, 5058-5067. doi: 10. 12659/msm.902022

Zhang, Q., Fan, H., Liu, H., Jin, J., Zhu, S., Zhou, L., et al. (2020). WNT5B exerts oncogenic effects and is negatively regulated by miR-5587-3p in lung adenocarcinoma progression. Oncogene 39, 1484-1497. doi: 10.1038/s41388019-1071-4
Zhang, Y., Lin, L., Jin, Y., Lin, Y., Cao, Y., and Zheng, C. (2016). Overexpression of WNT5B promotes COLO 205 cell migration and invasion through the JNK signaling pathway. Oncol. Rep. 36, 23-30. doi: 10.3892/or.2016.4772

Zhao, C., Yu, T., Dou, Q., Guo, Y., Yang, X., and Chen, Y. (2020). Knockout of TLR4 promotes fracture healing by activating Wnt/beta-catenin signaling pathway. Pathol. Res. Pract. 216:152766. doi: 10.1016/j.prp.2019.15 2766

Zheng, X., Fan, X., Fu, B., Zheng, M., Zhang, A., Zhong, K., et al. (2017). EpCAM inhibition sensitizes chemoresistant leukemia to immune surveillance. Cancer Res. 77, 482-493. doi: 10.1158/0008-5472.can-16-0842

Zheng, Y., Wang, C., Zhang, H., Shao, C., Gao, L. H., Li, S. S., et al. (2016). Polymorphisms in Wnt signaling pathway genes are associated with peak bone mineral density, lean mass, and fat mass in Chinese male nuclear families. Osteoporos. Int. 27, 1805-1815. doi: 10.1007/s00198-0153457-7

Zong, X., Wang, W., Ozes, A., Fang, F., Sandusky, G. E., and Nephew, K. P. (2020). EZH2-mediated downregulation of the tumor suppressor DAB2IP maintains ovarian cancer stem cells. Cancer Res. 80, 4371-4385. doi: 10.1158/0008-5472. can-20-0458

Conflict of Interest: The authors declare that the research was conducted in the absence of any commercial or financial relationships that could be construed as a potential conflict of interest.

Copyright (C) 2021 Suthon, Perkins, Bryja, Miranda-Carboni and Krum. This is an open-access article distributed under the terms of the Creative Commons Attribution License (CC BY). The use, distribution or reproduction in other forums is permitted, provided the original author(s) and the copyright owner(s) are credited and that the original publication in this journal is cited, in accordance with accepted academic practice. No use, distribution or reproduction is permitted which does not comply with these terms. 